\author{
UNITED STATES \\ DEPARTMENT OF THE INTERIOR \\ GEOLOGICAL SURVEY
}

Distribution of Precambrian mafic intrusives penetrating some Archean rocks of western North America

by

George I. Snyder ${ }^{1}$, David J. Hughes ${ }^{2}$, R. Peter Hall ${ }^{2}$, and Kenneth R. Ludwig ${ }^{1}$

Open-File Report 89-125

1989

This report is preliminary and has not been reviewed for conformity with U.S. Geological Survey editorial standards and stratigraphic nomenclature. The report has been inspired by International Geological Correlation Program Number 257, Precambrian Dyke Swarms, and it is listed as IGCP Project 257 Publication Number 7 .

IU.S. Geological Survey, Federal Center, Denver, Colorado 80225, USA

${ }^{2}$ Department of Geology, Portsmouth Polytechnic, Portsmouth PO1 3QL, UK 


\title{
Distribution of Precambrian afic intrusives penetrating some Archean rocks of western North Anerica
}

\author{
by \\ George L. Snyder ${ }^{1}$, David J. Hughes ${ }^{2}$, R. Peter Hall ${ }^{2}$, and Kenneth R. Ludwig ${ }^{1}$ \\ ${ }_{1}$ U.S. Geological Survey, Federal Center, Denver, Colorado 80225, USA \\ 2 Department of Geology, Portsmouth Polytechnic, Portsmouth PO1 3QL, UK
}

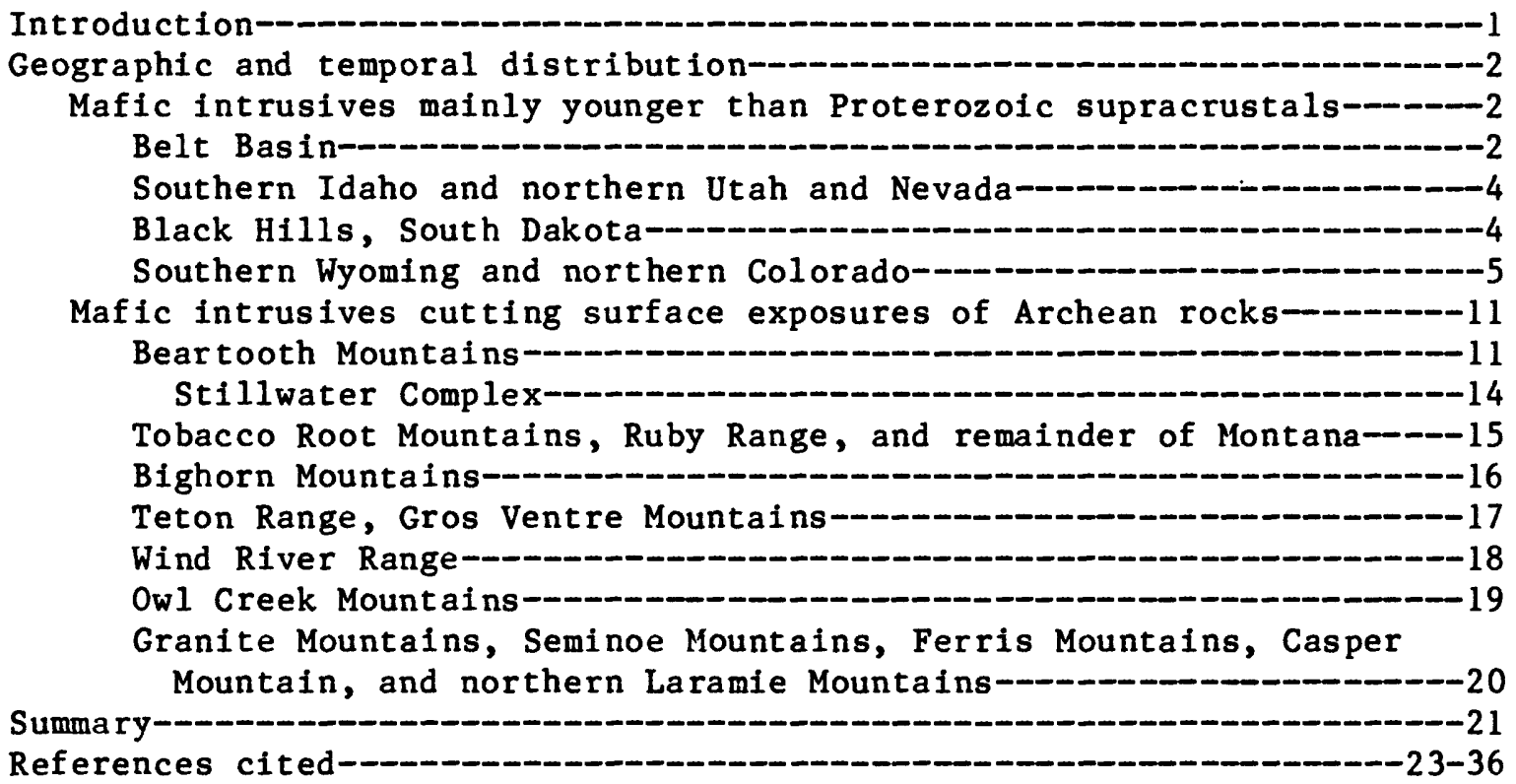

Introduction

An Archean craton is exposed in western America mainly in anticlinal or fault-block mountain ranges that are surrounded and covered by predominant Phanerozoic rocks (Reed, 1987). Exposures are generally excellent within these ranges. This paper describes the Archean and Proterozoic mafic and ultramafic intrusive rocks in this dominantly Archean terrane. Mafic and ultramafic intrusive rocks are common, forming a few batholiths, many swarms of dikes that constitute $\langle 1->20$ percent of the exposures, and widespread lenses, boudins, and irregular pods in gneisses. A little additional information comes from boreholes through the Phanerozoic cover (Peterman, 1971; Peterman and Futa, 1987; Tweto, 1987, p1. 1) and from xenoliths of gabbro, anorthosite, mafic amphibolite, and peridotite in Laramide intrusives (Brozdowski, 1985; Brozdowski and others, 1982; Dudás and Eggler, 1986; Eggler, 1987; Hearn and McGee, 1987).

In the surface exposures the mafic intrusives have been studied as the potential mineralogical or chemical samples of mantle, or of magmatic or metamorphic history that they represent, for the geometric and chemical clues to the tectonic regimes in which they were emplaced, and for the direct and indirect time constraints they impose or that are imposed upon them. Direct time constraints come from internal igneous radiometric ages of varying interpretation (some $\mathrm{K}-\mathrm{Ar}$ and $\mathrm{Rb}-\mathrm{Sr}$ ages seem to reflect younger chemical or metamorphic events by comparison with other $\mathrm{Rb}-\mathrm{Sr}$, or $\mathrm{Sm}-\mathrm{Nd}$ and $\mathrm{U}-\mathrm{Pb}$ ages). Indirect time constraints come from knowledge about the rocks or the structures the intrusives cut, or from younger sedimentary, metamorphic, or igneous events with a known time relation to the body in question. There is 
also the psychological milieu of the environment in which geochronological data are derived. Some authors perceive tightly time-constrained "events" while others tend to emphasize the time-continuum of the data. Criteria are derived only with great difficulty about how many mafic intrusive events are interspersed with how many metamorphic events, but each conscientious effort adds another building block to the structure of understanding. For useful reviews of Precambrian events compare Wooden (1975), Mueller (1979), James and Hedge (1980), Mueller and others (1982), and Harrison and Peterman (1984, pl. 1).

Rocks that penetrate Proterozoic rocks overlying Archean basement have a younger geologic time constraint than those that penetrate Archean alone; they will be described first in this report.

Geographic and temporal distribution

Mafic intrusives mainly younger than Proterozoic supracrustals

Belt basin

Mafic intrusives are extensive in the 15,000 stratigraphic $m$ of mildly metamorphosed rocks of the Middle Proterozoic (900-1450 Ma: Obradovich and others, 1984) Belt basin that were deposited at least partly on an Archean basement (Fig. 1). Called the Purcell sills in the U.S. and the Moyie sills in Canada and generally described as diabase, diorite, gabbro, metadiorite, and metagabbro, the rocks occur as sills and subordinate dikes (Hфy and Diakow, 1982; Mudge and others, 1982). Single sill thicknesses are usually described as 1-500 m (Harrison and others, 1985; Cressman, 1985; Cressman and Harrison, 1986; Harrison and others, 1986) and may reach $700 \mathrm{~m}$ (Bishop, 1973). The sills are concentrated in the lower part of the Belt section, the Prichard Formation of the U.S. or its Canadian equivalent, the Aldridge Formation, and generally occur at one to eight stratigraphic levels (Harrison, 1972; Harrison, in Hobbs, 1973; Cressman, 1985; Cressman and Harrison, 1986) but may be present at as many as 14 horizons in a single borehole (Harrison and others, 1985). Generally forming 6 percent of Aldridge measured sections ( $\mathrm{\phi} \phi y, 1985$ ) or 9 percent of lower Prichard map area (Harrison and others, 1986), the sills may increase in volume locally to expand the Prichard section 30 or 35 percent (Bishop, 1973; Harrison and others, 1985). "---the large volume of mafic rocks in the Purcell and Moyie sills of the Belt basin clearly indicate crustal fractures capable of tapping a mantle source" (Evans, 1986).

Although most of the sills and dikes are lithologically indistinguishable from one another, three periods of intrusion, about $1430,1100(?)$, and $800 \mathrm{Ma}$ (Hunt, 1962; Obradovich and Peterman, 1968; Zartman and others, 1982; Marvin and others, 1984; Harrison and others, 1986) (about 840 Ma locally: M.W. Reynolds, 3/28/88 written communication) have been recognized, and modern summary maps show two ages of intrusives (Cressman and Harrison, 1983; Harrison and others, 1986; Wallace and others, 1987). Most intrusive rocks are extensively altered: the former clinopyroxenes are nearly completely replaced by amphiboles, most plagioclases are clouded, and most magnetites oxidized, but the intrusive chill zones are thought to be compositionally representative of the original magma (Bishop, 1973). The amphibolitic alteration has been ascribed to regional deformation (Zartman and others, 1982 ) or to autometamorphism when magmas at $120{ }^{\circ} \mathrm{C}$ were emplaced in wet rocks at $300-350{ }^{\circ} \mathrm{C}$ (Bishop, 1973). 


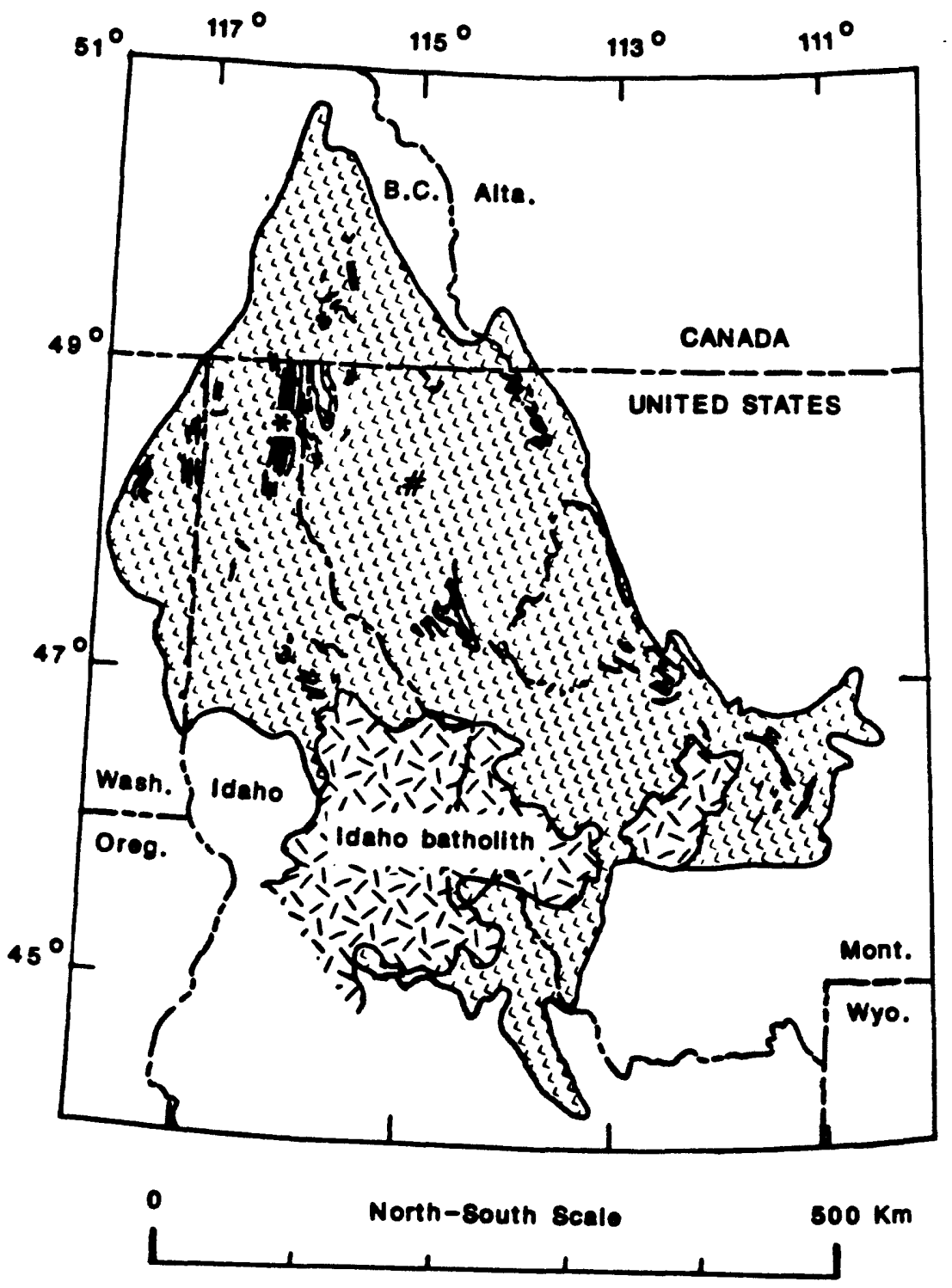

Figure 1. Known occurrences of Proterozoic mafic Intrusive rocks (black) within the outcrop area of the Belt Supergroup ("L" pattern). Locations of Crossport geochemical and geochronological locallty and No. 1 Gibbs borehole Indicated by * and \#, respectively. Sources Include: Ross and Forester, 1946; Ross and others, 1963; B1shop, 1973; Griggs, 1973; Aadland and Bennett, 1979; Hby, 1979, 1982, 1984; McMechan, 1979; Rember and Bennett, 1979; Hby and Diakow, 1982; Mudge and others, 1982; Harrison and others, 1983, 1985, 1986; Ruppel and others, 1983; Cressman, 1985, and 1987 written communication; Cressman and Harrison, 1986; Wallace, 1987; Wallace and others, 1987; and M.W. Reynolds and J.E. Harrison, 1988, written communications. 
Southern Idaho and northern Utah and Nevada

Unmetamorphosed Late Proterozolc supracrustal rocks over an Archean basement are preserved in the Portneuf and Bannock Ranges of southern Idaho and in the Uinta Mountains of northern Utah, but Precambrian mafic intrusives are rare. No Precambrian mafic intrusives have been mapped cutting the Late Proterozoic Pocatello Formation of southern Idaho (K.S. Kellogg, oral communication, $3 / 3 / 88$ ) but there are unmapped intrusive rocks associated with basaltic volcanic rocks in the Bannock Volcanic Member of the Pocatello Formation in the Bannock Range (Link and Le Febre, 1983, p. 5). These volcanics are high-Ti within-plate basalts that vary from transitional tholefitic-alkaline in the south to alkaline in the north and may have formed in a rift setting (Harper and Link, 1986).

Three altered diabase dikes 2-30 m wide and 4-15.5 km long trend westnorthwest through rocks of the Late Proterozoic Uinta Mountain Group in the central Uinta Mountains (Figure 2; Crittenden and others, 1967). These altered dikes contain remnant augite and pigeonite that originally constituted 15 percent of the rock ( $C . A$. Wallace, $3 / 2 / 88$ written communication). Some dikes are of uncertain age, but the easternmost dike has provided a $496+26 \mathrm{Ma}$ $\mathrm{K}-\mathrm{Ar}$ age (Ritzma, 1980) that is close to a $471 \mathrm{Ma} \mathrm{Rb}-\mathrm{Sr}$ age on a lone dark trachyte dike from Lodore Canyon (W.R. Hansen and P.E. Carrara, 1980 written communication), so the set may be early Paleozolc rather than Precambrian.

The exposed Archean terrane of northern Utah contains sparse amphibolitized mafic intrusives showing evidence of protolith emplacement at $2.74 \mathrm{Ga}$ in Weber Canyon (Bryant, 1988; Hedge, Stacy, and Bryant, 1983), at 1.8 $\mathrm{Ga}$ and between 2.6 and $3.0 \mathrm{Ga}$ in the Wasatch Range (Bryant, 1984; Hedge, Stacy, and Bryant, 1983), and between 1.85 and $2.6 \mathrm{Ga}$ on Antelope Island (Bryant, 1980; Bryant and Graff, 1980). Some amphibolites that contain metamorphic clinopyroxene or garnet in the Farmington Canyon Complex are cut by pegmatites (Bryant, 1988). West-northwest-, east-, and east-northeasttrending sills, dikes, and irregular bodies of amphibolite, hornblendite, and epidiorite as large as $2 \times 0.4 \mathrm{~km}$ occur in small areas of crystalline basement exposed in the northeast Uinta Mountains. They were intruded into strongly deformed metasediments and deformed and metamorphosed themselves prior to 1.5 Ga (Hansen, 1965).

Large mafic or ultramafic intrusive bodies do not appear to be part of the description of the Archean terrane in the Albion Range and nearby mountains on the Utah-Idaho border (Armstrong and Hills, 1967; Compton, 1980; Miller, 1980; Salzer and Hodges, 1988; Todd, 1980). However, the Wyoming Province has recently been extended some $160 \mathrm{~km}$ southwest from the Albion Range into northeast Nevada's northern East Humboldt Range (not shown on fig. 2) where newly dated $2.5 \mathrm{Ga}$ gneisses contain numerous amphibolitic bodies interpreted as mafic intrusions (Lush and others, 1988).

\section{Black Hills, South Dakota}

Metamorphosed differentiated gabbrolc sills of three Early Proterozolc ages cut supracrustal rocks in the Black Hills uplift, especially on the north and east sides (Dewitt and others, 1986), and Archean ultramafic rocks probably were present also (Redden and others, 1988). The oldest Proterozoic mafic intrusive mass $(2.2 \mathrm{Ga})$, the 900-m thick Blue Draw Metagabbro near Nemo (Redden, 1981), is gravity layered and consists, from bottom to top, of 45- . $90 \mathrm{~m}$ of carbonatic serpentinite (former olivine concentration), somewhat thicker hornblendite (former pyroxenite), much thicker amphibolite, and local 
granodiorite (Redden, 1980). Younger, layered metagabbro sills are similar but postdate a post-Blue Draw unconformity and have been dated at $2.0 \mathrm{Ga}$ near Bogus Jim Creek and $1.9 \mathrm{Ga}$ near Prairle Creek (Z.E. Peterman, 3/28/88 oral communication; Redden and others, 1988). The sills are as thick as $300 \mathrm{~m}$, are more differentiated in the direction that is stratigraphically younger, and are similar in age to overlying volcanic rocks. All the metagabbros were deformed, amphibolitized, and intruded by granite at about $1.7 \mathrm{Ga}$ (Redden, 1980; Dewitt and other8, 1986). Detrital chromite in earliest Proterozoic metaconglomerate indicates that ultramafic rocks were probably exposed in the Archean terrane although none now crop out (Redden and others, 1988, ms. p. 13 and 31 ).

\section{Southern Wyoming and northern Colorado}

Mafic intrusives of at least three Proterozoic ages $(2.0-2.1,1.77$, and $1.4 \mathrm{Ga}$ ) in southern Wyoming and northern Colorado penetrate Early Proterozoic supracrustal rocks that themselves unconformably overlie a granitic basement containing a fourth set of Archean mafic intrusives $(>2.5 \mathrm{Ga})$. The oldest two groups can be distinguished radiometrically but not lithologically, and the youngest two groups also contain some overlapping lithologies but generally can be distinguished from each other and from the older two by their structural habit or lithologic association.

In the Medicine Bow Mountains and Sierra Madre Archean intrusives are deformed along with their quartzofeldspathic gneiss country rock into northand northwest-trending folds in a fold system at a large angle to fold directions in overlying Early Proterozoic metasedimentary rocks. These intrusives plus other garnet amphibolites and peridotites cutting Archean basement are inferred to be Archean (Houston and others, 1968; Divis, 1973, 1976; Houston and Ebbett, 1977; Karlstrom and others, 1981). In the

Figure 2. General distribution of mafic intrusives in the Archean mountain ranges of the Wyoming Province. Base from Houston, 1988. Archean and Early Proterozoic intrusives, mostly metamorphosed, shown in green; Middle and Late Proterozoic intrusives, mostly not metamorphosed, shown in red. Distribution highly generalized; age determinations, shown in billions of years, vary from precise to estimates only. Derived from many sources, Including Armbrustmacher, 1972, 1977; Barker, 1982; Bayley, 1968; Bayley, Proctor, and Condie, 1973; Becraft and others, 1966; Berg, 1979; Bryant, 1984; Casella, 1979; Casella and others, 1982; Condie, 1982; Condie and others, 1969; Dewitt and others, 1986; Ell1ott and others, 1983; Erslev, 1981, 1983; Ferris and Krueger, 1964; Fraser and others, 1969; Gable, 1987; Gable and others, 1988; Granger and others, 1971; Hansen, 1965; Hausel and others, 1985; Houst on and others, 1968, 1988; Houston and Ebbett, 1977; Houston and Karlstrom, 1979; Houston and Orback, 1976; Kar1strom and others, 1981; Killsgaard and other8, 1972; Koehler, 1976; Manzer and Heimlich, 1974; $0^{\circ}$ Ne111 and others, 1988; Page and Nokleberg, 1974; Pearson and others, 1971, 1973; Peterman and Hildreth, 1978; Prinz, 1964; Reed and Zartman, 1973; Ruppel and others, 1983; Schmidt and Garihan, 1986; Scholten and others, 1965; Segerstrom and others, 1976; Segerstrom and Carlson, 1982; Simons and others, 1979; Snyder, 1980a, 1980b, 1984, 1986; Snyder and Hedge, 1978; Spencer and Kozak, 1973, 1975; Stuckless and Peterman, 1977; Stueber and others, 1976; Tweto, 1987; Tysdal and others, 1987; Vitaliano and others, 1979; Wedow and others, 1975; Witkind, 1972, 1976; Wooden and others, 1978; Worl and others, 1986. [Illustration on next page.] 
LITTLE AOCKY MOUNTANS

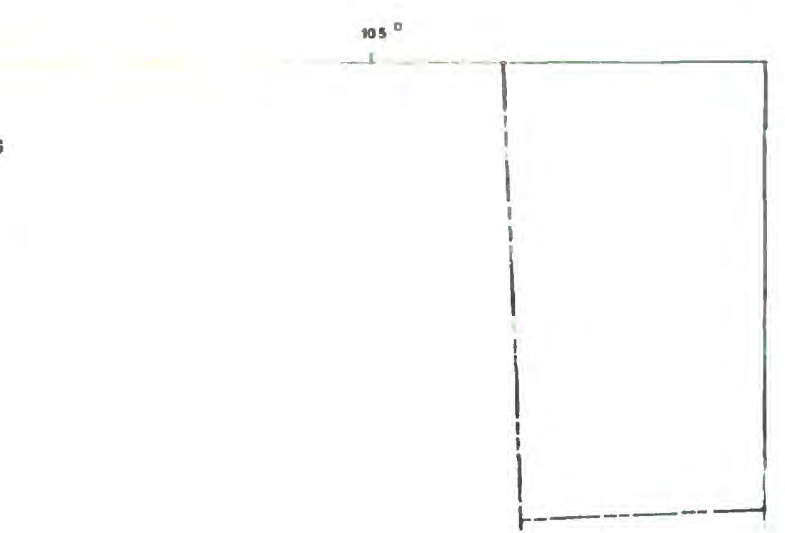

$\int_{1}^{2}+5$

TOBACCO ROOT MOUNTAINS

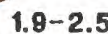

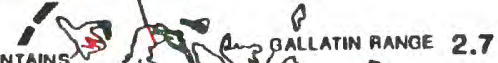

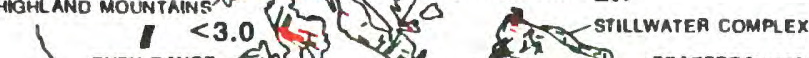

RUBY RANGEY LW

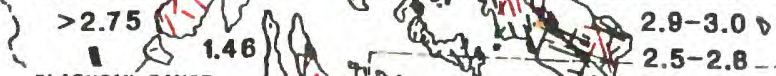

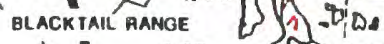

311.13

st

1

$2.1-2.2$

1.3

0.7

2.8

2.2

GHORN MOUNTANS

1.8-2.1

ETON RANGE

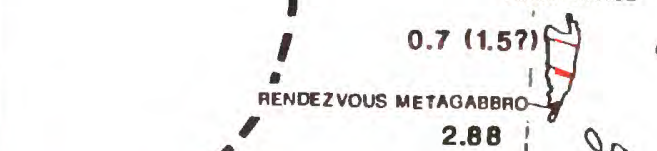

1
1
1
1
1

$\circ 0$

OWL CAEEK MOUNTANS

3.0

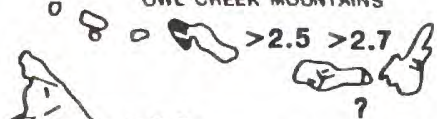

$7 ?$

GROS VENTRE MOÚNTAINS

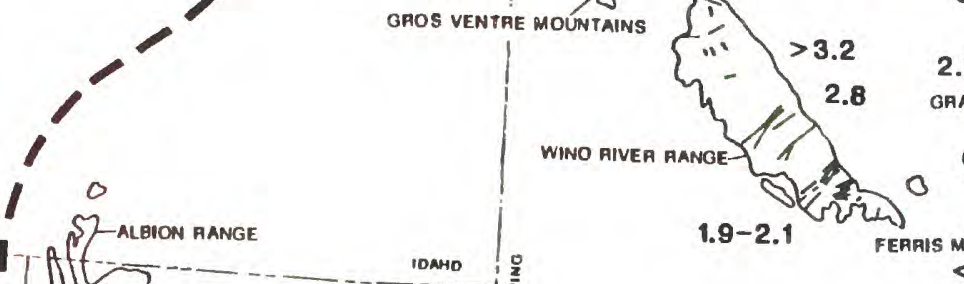

$2.6-2.9<2.6$

2.5-2.8

GANITE MOUNTAINS CASPER MOST

(An)

2.58

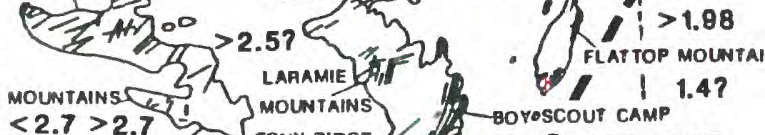

$>2.5 ?$

SEMINOE MOUNTAINS TONY AIDGE-

$0>2.5$ ? MOUNTAINS

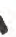

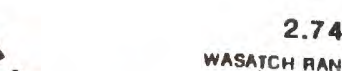

$\underset{\text { antelope ISLAND-O }}{1.85-2.6}\left\{\begin{array}{l}2.6-3.0 \\ 1.6\end{array}\right.$

- unta mountains

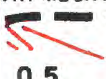

sis:

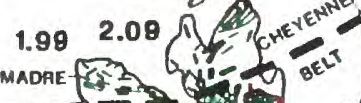

-lahamie anohthosite complex
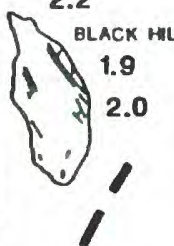

sourm daxota

MEBRASX

\section{OUNTAIN}


Hartville uplift dikes of granular quartz amphibolite are colinear on a 2.58granite $\mathrm{Rb}-\mathrm{Sr}$ isochron dlagram and are mainly older than the $1.98 \mathrm{Ga}$ granite of Flattop Butte (Figure 3, this report; Snyder and Peterman, 1982).

A voluminous swarm (20 percent of a granite gneiss terrane) of mainly northeast-trending mafic and ultramafic dikes in the central Laramie Mountains varies from older plagioclase-porphyritic metabasalt through nonporphyritic metadiabase or basaltic komatiite (Snyder, 1984) to variously altered metaperidotite and serpentinite (Figure 4, this report). With compositions that suggest extensive post-2.6-Ga mantle melting (Holden and Snyder, 1983), the dikes have $\mathrm{Sr}$ isotope ratios and REE patterns that suggest two distinct mantle sources (Snyder and others, 1985). Most mafic diabases were derived from a fertile mantle source, and most ultramafic rocks originated from a depleted harzburgitic mantle (Hall and others, 1987). Emplacement of the dikes pre-dated at least one period of metamorphism and deformation, because most of the diabase dikes contain metamorphic garnet and some are folded and display axial-plane foliation. New U.S. Geological Survey radiometric data indicate that many, perhaps most, representatives of this dike swarm are Early Proterozoic, especially in the vicinity of the Boy Scout Camp on the North Laramie River (Figure 3). Here a swarm of garnet amphibolite dikes cuts across and is about equally voluminous within a $6-\mathrm{km}-1$ ong granodiorite pluton centered on the Boy Scout Camp (Snyder, 1986, part B) from which zircons were dated by R.R. Ludwig in March 1988 at 2,051+10 Ma. Some dikes of the garnetamphibolite dike swarm are cut by the pyroxene granite in the Richeau Hills ( $30 \mathrm{~km}$ to the east southeast; Snyder, 1984, part L) from which zircons have been newly dated at $1740+20 \mathrm{Ma}$ (a $3 / 28 / 88$ improvement on the $1700 \mathrm{Ma}$ preliminary data reported in Snyder, 1984). Most of the swarm, therefore, falls in the range $1.74-2.05 \mathrm{Ga}$. It is conceivable that some of the dikes could fall in the age range between the granite of Flattop Butte and granodiorite of Boy Scout Camp ( $60 \mathrm{~km}$ apart) at $1.98-2.05 \mathrm{Ga}$ if the swarms are coextensive under cover and if the $2.58 \mathrm{Rb}-\mathrm{Sr}$ collnearity reasoning mentioned above does not apply to all the dikes.

Earliest Proterozoic mafic and ultramafic intrusives are well dated in the Sierra Madre and probably are present in other terranes as well. A $1.99+0.03 \mathrm{Ga} \mathrm{Sm}-\mathrm{Nd}$ mineral and whole-rock isochron is reported from the 2-kmlong Spring Creek Lake olivine norite body that cuts Archean granite in the central Sierra Madre (see Rarlstrom and others, 1981, pl. 5; Shaw and others,

Figure 4. Intrusive relations exposed in north wall of North Fork Cherry Creek, central Laramie Mountains. Average evergreen tree is $15 \mathrm{~m} \mathrm{tall.}$ Exposed rock relationships, from oldest to youngest, are:

1) Archean granite gneiss (light, in right half of photograph) with gneissic layering and foliation (light- and medium-gray layers) sloping from upper left to lower right.

2) Archean or Early Proterozoic metatholeiltic amphibolite dikes (1-20 m dark layers marked with arrows in right half of photograph) extending from upper right to lower left and cutting granite gneiss at a high angle.

3) Dark, jointed Archean or Early Proterozolc peridotite of Tony Ridge in upper left of photograph, with lower contact cutting granite gneiss at a high angle and some amphibolite dikes at a low angle. Perldotite varies from websterite at rare contact exposures to harzburgite, Iherzolite, and olivine websterite within body; richest in olivine near center of body.

4) Asterisks mark localities at which late $2-75 \mathrm{~cm}$ wide dikes of olivinephyric norite (not visible on photograph) cut peridotite.

[Illustration on next page.] 


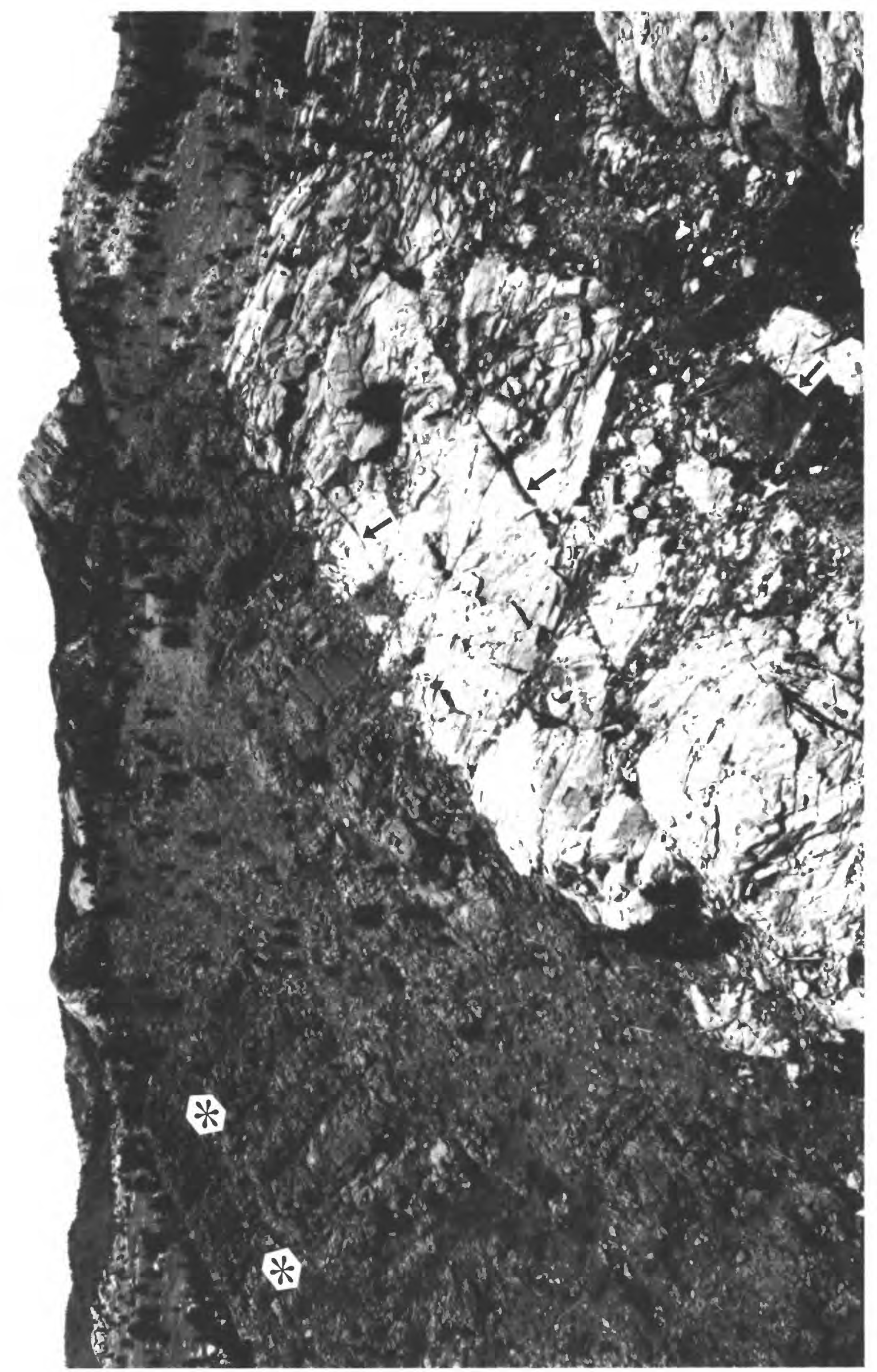


1986; and Tracy and others, 1986); the Rb-Sr systematics are imprecise. Eighteen kilometers to the east-southeast a pegmatitic phase of the 1.3-kmlong Cushman Creek metagabbro plug in Cascade Quartzite has yielded a 2092 \pm 9 $\mathrm{Ma} \mathrm{U-Pb}$ age on four zircon fractions (Premo and Van Schmus, 1988). Thus intrusions described as boninitic and tholeiltic are known to have been active in the Sierra Madre in earliest Proterozoic time. Metaharzburgites and metatholeites are present in the central Laramie Mountains (Fig. 4) but are not closely dated internally; one differentlated body on Sellers Mountain has a metaperidotitic base and a metabasaltic top (Langstaff, 1984). Davis and others (1977) reported an Rb-Sr isochron on the peridotite of Preacher Creek in the Laramie Mountains that shows much scatter between 1.72 and $4.41 \mathrm{Ga}$. In the Hartville uplift the anatectic granite of Flattop Butte, Rb-Sr age $1.98 \mathrm{Ga}$ (Snyder and Peterman, 1982), is cut by only one amphibolite dike (compared to a dense swarm of now-granular amphibolite dikes in the Archean granite) (see Figure 3 above). In the Medicine Bow Mountains the altered Gaps intrusive is about $2.0 \mathrm{Ga}$ (Karlstrom, 1981, p. 280).

Three or four layered synvolcanic batholithic plutons, one covering as much as $1558 \mathrm{~g} \mathrm{~km}$, and numerous smaller intrusives cut Early Proterozolc rocks just southeast of the Archean craton (Houston and others, 1968; Snyder, 1980a; Karlstrom and others, 1981, fig. 3.1). The major plutons, from northeast to southwest the Lake Owens Mafic Complex (Houston and others, 1968; Houston and Orback, 1976), the Mullen Creek Mafic Complex (R.J. Chico, 1987 oral communication; Edwards, 1981; R.R. Loucks, 1987 written communication), and the gabbro of Elkhorn Mountain (Snyder, 1980a; only this body is named on $f$ ig. 2), are progressively more amphibolitized from northeast to southwest but even the Lake Owens body, which contains abundant gabbronorite and troctolite, is amphibolitized near its southern contact. The Lake Owens pluton is a layered mafic complex $5.8 \mathrm{~km}$ thick that is believed to have been derived from a high $\mathrm{SiO}_{2}$ primary magma that was replenished in the magma chamber with more mafic liquids (R.R. Loucks, 1987 written communication; Myers and Patchen, 1987; Patchen and Myers, 1987). One of these plutons that is directly dated is the gabbro of Elkhorn Mountain, where zircons from a diorite phase were originally dated by Carl Hedge at $1.78 \mathrm{Ga}$ (Snyder, 1980a); the date on the same zircon separate has recently been refined to $1.77 \mathrm{Ga}$ (Pallister and Aleinikoff, 1987; Reed and others, 1987, table 1, \#5), essentially identical to a 1,778+2 Ma age on a quartz diorite phase of the Mullen Creek Mafic Complex (W.R. Premo and R.R. Loucks, 6/2/88 written communication; Loucks, and others, 1988). A N. $20^{\circ}$ E. set of basalt dikes cuts the gabbro of Elkhorn Mountain and some immediately adjacent wall rocks (Snyder, 1980a).

A northwest-trending set of $1.4 \mathrm{Ga}$ lithologically diverse dikes is found on both sides of the Cheyenne Belt, a shear zone at the southeast margin of the Archean continent; they are structurally simple themselves but frequently cut across earlier complex fold structures at high angles. The famous "Iron Dike" of this set is a diabase with 8.5 percent titaniferous magnetite that is as much as $45 \mathrm{~m}$ thick, dips steeply southwest, and is traceable across the northern Colorado Front Range for $130 \mathrm{~km}$ (Wahlstrom, 1956; Tweto, 1987). As noted by Tweto ( $p . A 40$ ), "a mafic dike of this length must reflect a major fracture deep in the crust". A ubiquitous near-vertical flow lineation indicates "that the diabase magma rose vertically throughout the length of the dike and thus that the deep source was widespread". Colinear with this dike in the Medicine Bow Mountains south of the Cheyenne Belt is a zone of northto north-northwest-trending porphyritic quartz latite dikes that cut all Precambrian units except the youngest, the 1.43-Ga Sherman Granite. Late northwest-trending dikes in the Laramie Mountains vary from diabase through 
biotite basalt south of the Cheyenne Belt $(1.42+0.07 \mathrm{Ga}$ biotite $\mathrm{K}-\mathrm{Ar}$ date from Ferris and Krueger, 1964) to rhyolite north of the Cheyenne Belt in the Richeau Hills ( $1.45+0.03 \mathrm{Ga} \mathrm{Rb-Sr}$ whole rock date by Z.E. Peterman in Snyder, 1984). Hartville upilft dikes of northwest trend include amphibolites that cut the $1.74 \mathrm{Ga}$ granite of Haystack Range and olivine basalt that cuts folded metasedimentary rocks northeast of Guernsey, Wyoming (Snyder, and others, 1989, fig. 5D). In the northern Park Range of Colorado dikes of this general age include porphyry dikes of two sets, a northwest set faulted by a northeast-trending mylonite zone and cut by the $1.47 \mathrm{Ga}$ Roxy Ann Lake phase of the Mount Ethel pluton, and a northeast $8 \mathrm{et}$ that cuts the Roxy Ann Lake phase (Snyder and Hedge, 1978). Possibly some undated northwest-trending dikes in the Uinta Mountains of Utah that were mentioned earlier could also be Middle Proterozoic.

Mafic intrusives cutting surface exposures of Archean rocks

\section{Beartooth Mountains}

The mafic intrusives cutting Archean crystalline rocks of the Beartooth Mountains, Wyoming and Montana, have been more intensively studied than the mafic intrusives of any other range in the Wyoming province. Not only is the Stillwater Complex (relations summarized in next section) present in this range, but there is also a suite of excellently exposed, mainly northwesttrending mafic dikes that span a range of compositions and ages. Interspersed with the intrusive events are two or three major metamorphic events that have been described and summarized by Gilett1 (1966), Brookins (1968), Fraser and others (1969), Skinner and others (1969), Rowan and Larsen (1970), Casella (1979), Mueller (1979), Casella and others (1982), lueller and others (1982), Loferski (1986), and others.

The early workers recognized 3 or 4 periods of mafic intrusion. The first consisted of prefolding, premetamorphic, pregranitic orthoamphibolite or metagabbro; this was followed successively by intrusion of metabasalts or metadolerites that cut pegmatites, then by quartz dolerite, and finally by ollvine dolerite (Ecklemann and Poldervaart, 1957; Spencer, 1959; Prinz, 1964; and Casella, 1969). Prinz (1964) noted that the metadolerite dikes contain local scapolite but not garnet; rock types grouped with the metadolerites include metaharzburgite, metabronzitite, "leopard rock" (large-plagloclasephyric rock with nonporphyritic borders), and intrusion breccia; the younger dolerites contained vesicles. Rowan's (1969) and Casella's (1969) maps of part of the northeast Beartooths show several meaningful intersections of mafic, ultramafic, and pegmatitic intrusions, and others have also mapped mafic intrusive crosscutting relations in other parts of the Beartooths (Fraser and others, 1969; Reid and others, 1975; Wedow and others, 1975; Simons and others, 1979; Casella and others, 1982; Segerstrom and Carlson, 1982; Timm, 1982; E111ott and others, 1983). Numerous attempts to apply various radionetric dating techniques have been made (Condie and others, 1969b; Mueller, 1970, and 1971 written communication; Rowan and Mueller, 1971; Baadsgaard and Mueller, 1973; Mueller and Rogers, 1973; Wooden, 1975 written communication; Wooden and Mueller, 1979; Wooden and others, 1981, 1982). The Beartooth mafic intrusive history was summarized by Mueller and others (1982) as follows: 
Dioritic amphibolite--

Stillwater Complex- $2.7 \mathrm{Ga}$

Early mafic dikes (contain clinopyroxene but all are hypersthenenormative according to Raby and others, 1979)-

Additional mafic dikes--

Olivine-normative dikes- $1.3 \mathrm{Ga}$

Quartz tholeiite-_ $0.7 \mathrm{Ga}$.

One complication volced by Skinner (1969) is that some pre-2.79-Ga eastern Beartooth ultramafic pods were tectonically emplaced, broken into lenses near fold crests, and variably recrystallized to nonequilibrium assemblages in several later events. He maps 18 equidimensional to lensshaped bodies $4.5-140 \mathrm{~m}$ long in a granitic gneiss group elongated $\mathrm{N} .65^{\circ} \mathrm{E}$. over a distance of $650 \mathrm{~m}$. Northwest of this area the Red Lodge chromitebearing ultramafic bodies described by James (1946) have been affirmed by Loferski (1980 written communication; 1986) to be the disrupted fragments of a large stratiform complex.

The history of correlation between intrusive orientation and age has been complicated. Spencer (1959) recognized that the various groups of Beartooth mafic dikes occupied some of the same fracture trends, and Prinz (1965) commented that Archean fracture patterns exerted a strong influence on later intrusion. Condie and others (1969b) cautioned that there was no apparent relation between dike age and dike trend. Apparently the dike swarms of the Beartooths differ from those of the Canadian shield in that they are more iimited in occurrence and are generally not separable into compositional or age groupings on the basis of strike (Wooden, 1975). But Wooden (1975) and Wooden and Mueller (1979), while recognizing 4-5 age groups as well as 17 chemical groups of dikes, nevertheless see some trend consistency amongst Proterozoic dikes as compared to a diversity of orientation within the Archean dike group. Those 2000-2100 Ma old are described as generally oriented northsouth, the 1300-Ma group is consistently N. $30^{\circ} \mathrm{W}$, , and the 740-Ma group is consistently N. $75^{\circ} \mathrm{W}$. Wooden and Mueller noted further that "as a general rule, one chemical grouping is restricted to a limited geographic area and consistently oriented fractures. Only the $1300 \mathrm{~m} \cdot \mathrm{y}$. old alkali olivine diabases have been found all across the Beartooths. Some chemical groups are represented by a single known dike,---others by more than a half dozen. It is not unusual for different chemical types to occupy the same fracture with segments placed end-to-end but not side-by-side. The variety of chemical groups and the variously oriented fractures that they occupy suggest that the 2800-2500 m.y. old group represents a number of distinct magmas intruded over a period of time during which the orientation of the tectonic stress field changed. The 2200-2100 m.y. event encompasses 2-3 magma types but the stress field seems to have remained constant. The two younger events represent single pulses of magma. The pattern of intrusion in the Beartooths appears to go from the complex to the simple with decreasing age--The extensive nature of the $1300 \mathrm{~m} \cdot \mathrm{y}$. event is probably related to the tectonics of the Belt basin which was active between $1450 \mathrm{~m} \cdot \mathrm{y}$. and $900 \mathrm{~m} \cdot \mathrm{y} \cdot$ ago and the main axis of which is oriented parallel to the trend of the $1300 \mathrm{~m} \cdot \mathrm{y}$. old dike swarm---".

Simons and others (1979, plate 1) mapped six varieties of Precambrian maflc dikes in $1700 \mathrm{sq} \mathrm{km}$ of the eastern Beartooth Mountains. Figure 5 shows a rose diagram of orlentations for each of Simons groups of dikes. Figure 5 and Simons map show that different map groups of mafic dikes do indeed have distinct preferred orientations, albeit some more complicated than others. Simons map also shows various age relations between some members of the different dike groups: quartz dolerite cuts metadolerite in one place, 

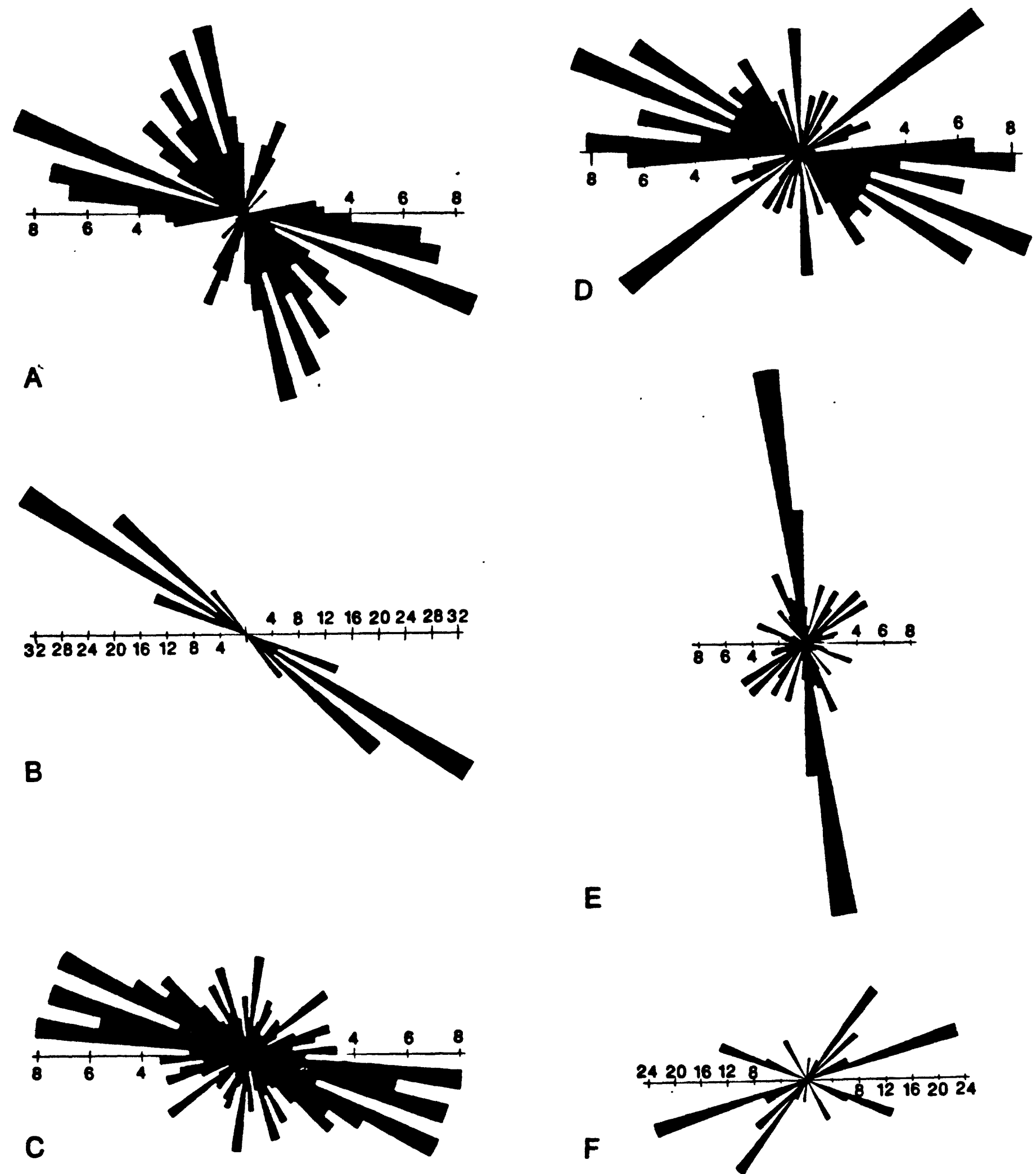

Figure 5. Evenly length-weighted rose diagrams for labeled Precambrian mafic dikes of the eastern Beartooth Mountains, derived from the map by Simons and others (1979, plate 1). A = quartz dolerite dikes ( $37 \%$ of data); $B=$ alkalic olivine dolerite dikes ( $3 \%$ of data); $C=$ metadolerite dikes ( $39 \%$ of data); $D$ = unassigned dikes (9\% of data); E = amphibolite and hornblende gneiss ( $11 \%$ of data); $F=$ ultramafic rocks ( $1 \%$ of data). A-D mapped as Late Archean through Proterozoic; E, F mapped as Late Archean. Percentage scale lines oriented east-west in each diagram with north at top; note different scales for different diagrams. 
metadolerite cuts metadolerite in one place, and amphibolite and hornblende gneiss are cut by quartz dolerite ( 4 places), alkalic olivine dolerite (one place), and metadolerite (6 places). Because many dikes are shown as lines, all other map intersections are non-diagnostic. Simons' (1979) alkalic olivine dolerite (orientation concentration is $\mathrm{N} .55-60^{\circ} \mathrm{W}$. ) is doubtless equivalent to Wooden and Mueller's (1979) alkalic ollvine diabase ( $1300 \mathrm{Ma}$ and "consistently N. $30^{\circ}$ W.") but other correlations between the dike groups of these respective authors are less clear. Wooden and Mueller's N. $75^{\circ}$ W.trending 740 Ma dikes are probably included with the more diversely oriented quartz dolerites of Simons and others (1979). But it seems unlikely that Wooden and Mueller's north-trending 2000-2100 Ma dikes should be included with the strongly north-trending amphibolite and hornblende gneiss of Simons and others (1979); they are likely a small percentage of some other Simons ${ }^{-}$ group. It is not clear whether Wooden and Mueller's Archean group is spread over several of the Simons-derived diagrams or whether it is concentrated in one.

St1llwater Complex. The St1llwater Complex is a coarse-grained postorogenic, strongly differentiated mafic and ultramafic intrusive body emplaced in the northern Beartooth Mountains at $2.7 \mathrm{Ga}$ (Nunes and Tilton, 1982; DePaolo and Wasserburg, 1979; Lambert, Unruh, and Simmons, 1982). Differentiation of basaltic magmas produced layered mixtures of the cumulate minerals, olivine, bronzite, plagioclase, and augite, forming a sequence $5.5-7.7 \mathrm{~km}$ thick. For descriptive summaries see Czamanske and Zientek (1985) and Page and Zientek (in Houston and others, in press 1988) and for geologic maps see Page and Nokleberg (1974) and Segerstrom and Carlson (1982). The Stillwater Complex 11 kely records repeated influxes of new magma into a quiescent pool of differentiating magma (Todd, Schissel, and Irvine, 1979; Lambert and Simmons, 1980; McCallum, Raedeke, and Mathez, 1980; Irvine, Keith, and Todd, 1982; Bow and others, 1982; and many others, but also see Ryder and Spettel, 1985). Primary magmas proposed include komatilte, picrite, tholeilte, and anorthosite. The profusion of cumulates makes deduction of magmatic liquids difficult, and attempts to do so have concentrated on high-Mg dikes in the Beartooth Mountains, or on chilled-margin dikes and sills of the stillwater Complex.

Six geochemically distinct groups of Precambrian high-Mg Beartooth dikes were examined by Longhi and others (1983) to see if any could have been the parent magma of the Stillwater Complex; they state that "only two groups have sufficiently magnesian olivine and orthopyroxene, but nelther of these has sufficiently calcic plagioclase." One dike of one of these groups, which intrudes and is chilled against one of the Stillwater cumulate zones in the eastern part of the complex, has a preliminary 2-point Sm-Nd mineral isochron indicating a $2.65 \mathrm{Ga}$ age. Longhi and others (1983) say that the re appear to be two distinct magma types parental to the high-Mg Beartooth dikes, these having 11 and 13 percent $\mathrm{MgO}$, and that several different fractionating komatific parent magmas with varying amounts of crustal contamination seem required to explain their geochemical models.

Study of chilled-margin $8111 \mathrm{~s}$ and dikes originally indicated two types of basal series liquids: 1) Sulfide-poor feldspathic diabase, and 2) Sulfidecontalning mafic norite (Zlentek, 1983). Additional study of these basal precursor sills has indicated that there are as many as six magmatic groups, of which two groups, mafic norite and high-Mg gabbronorite with 9.6-13 percent Mg0, formed the dominant Stillwater liquids, while olivine gabbro, with 6.47.6 percent MgO, formed a minor additional liquid (Helz, 1985). All the 
precursor-sill magmatic groups are said to be different from post-stillwater dikes in the area and more satisfactory for the determination of St1llwater liquids (Helz, 1985, 1987). One basal norite dike from the Mountain View area has recently yielded zircons with a $2,713 \pm 3 \mathrm{Ma}$ age (Premo and others, 1986).

Proterozoic and Archean dikes of dolerite, metadolerite, and plagioclaseporphyry basalt intrude the Stillwater Complex along trends from east-west in the western part of the complex, through east-northeast and northeast in the central part, to north-northwest in the eastern part, but there are many varlations. Many dikes were emplaced along faults and some are sheared. Dikes are as wide as $0.5 \mathrm{~km}$ locally (Baadsgaard and Mueller, 1973; Page and Nokleberg, 1974; Segerstrom and Carlson, 1982).

Tobacco Root Mountains, Ruby Range, and the remainder of Montana

The alternation of mafic intrusive and metamorphic events in southwest Montana west of the Beartooth Mountains (see f1g. 2) has been summarized by James and Hedge (1980) as follows:

1) Widespread emplacement of pre-metamorphic pre-deformation mafic sills and dikes (now sheets, lenticular bodies, and boudins of amphibolite and hornblende gneiss) after sedimentation at 3,000 Ma or before.

2) Local emplacement of mafic sheets after two folding events but between two major metamorphisms, the youngest of which culminated 2,750 Ma.

3) Emplacement during regional uplift of diabase dikes at 1,455 and about $1,125 \mathrm{Ma}$ (after Wooden and others, 1978).

In the Tobacco Roots and adjoining Ruby Range a swarm of 1,455-Ma dikes were primitive tholeiltes with $0.2-0.8$ percent $\mathrm{K}_{2} \mathrm{O}$ while other dikes were more differentiated or contaminated quartz-normative tholelites with $1.1-1.6$ percent $\mathrm{K}_{2} \mathrm{O}$. the dikes at about $1,125 \mathrm{Ma}$ came from two separate magmas, one with $\mathrm{FeO}_{\mathrm{T}}$ between 8.9 and 10.4 percent, the other with $\mathrm{FeO}_{\mathrm{T}}$ between 13.6 and 15.8 percent. In the southern Tobacco Roots west-northwest-trending fractures were filled magmatically in an overlapping sequence beginning in the southwest and proceeding to the northeast. Some dikes had their isotopic systems disturbed when later dikes were intruded beside them (Wooden and others, 1978).

Besides the $17 \mathrm{~km}$ long swarm of unmetamorphosed diabase dikes addressed above (Koehler, 1976; and Wooden and others, 1978), there is an equal volume of pre-pegmatite metabasic intrusive sheets and meta-ultramafic pods in the Tobacco Roots. Many student have noted in theses that the older mafic Intrusives were emplaced as sheets between an early granulite-facies metamorphic event and a later amphibolite facies event; some are cut by metamorphosed shear zones (McCulloch and Cummings, 1987, 1988). The pre- and post-metamorphic sheets were emplaced at right angles to each other signalling an important change in the Precambrian stress field between the times of their respective emplacements: West-northwest post-metamorphic dikes cross the trend of north-northeast pre-metamorphic dikes, with one intersection mapped, in the southern Tobacco Roots; northwest post-metamorphic dikes cross the northeast- to east-trending pre-metamorphic dikes in the northern Tobacco Roots. In addition north-trending meta-ultramafic pods are shown transecting east-west metabasite sills at six localities in the northern Tobacco Roots; one meta-ultramafic pod appears at the center of a metabasite pluton in the coutheast Tobacco Roots (V1tallano and others, 1979).

Pre- and post-metamorphic mafic intrusives also occur in other ranges in couthwest Montana. In the Ruby Range meta-ultramafic rocks were emplaced prior to an upper-amphibolite-facles event. Typically they are texturally and 
mineralogically zoned, occur along fold crests, and locally alternate with pegmat1tes in boudinage structure (Garihan, 1979; Desmarais, 1981). Younger, northwest-trending diabase dikes cut the ultramafics (Heinrich, 1960;

Karasevich and others, 1981).

In the southern Madison Range, and the Centennial Mountains south of this, Archean volcanics contain pre-metamorphic bronzititic ultramafic pods that may represent komatiite flows and intrusives. These were followed by structure-crossing north-northwest to northeast-trending diabasic quartz tholeifte and gabbro dikes and sills as long as $4.5 \mathrm{~km}$, some of which occur along and one of which cuts the northeast-trending Madison mylonite zone (Erslev, 1981, 1983; Witkind, 1972, 1976).

The northern Madison and Gallatin Ranges also contain lenses of wehrlitic Intrusives and three age groups of northwest- to northeast-trending mafic sheets (oldest first): 1) Folded and boudinaged foliated amphibolites, 2) Unfolded, follated amphibolites, 3) Unfolded, unfollated diabase and basalt (Becraft and others, 1966; Spencer and Kozak, 1975).

The Highland Mountains cratonic rocks contain two generations of mafic intrusives: northeast- to east-trending metabasite dikes, and northwest- to west-trending diabase dikes ( $0^{\prime} \mathrm{Ne} 111$ and others, 1988). A rose diagram of 117 (younger) diabase dikes greater than $100 \mathrm{~m}$ long in the Tobacco Root and Highland Mountains and Ruby and Madison Ranges shows a strong concentration in the N. $30-80^{\circ}$ W. sector (Schmidt and Garihan, 1986, fig. 4).

Precambrian mafic and ultramafic intrusives are also present in the less completely studied Greenhorn and Gravelly Ranges, which occur between the Madison and Ruby Ranges (Hadley, 1969; Berg, 1979). In the Blacktall Range a $1.6 \mathrm{~km}$ unmetamorphosed harzburgite intrusive is cut off by the Dillon Granite Gneiss (Scholten and others, 1955); northwest-trending unfoliated diabase dikes are the youngest Precambrian features in this range (Clark and Mogk, 1985). Metadiorite (Pinto Diorite), metagabbro, and crosscutting metabasaltic dikes were intruded between 2.5 and $1.9 \mathrm{Ga}$ metamorphic events in the Neihart area of the Little Belt Mountains (Catanzaro and Kulp, 1964; Catanzaro, 1967; Witkind, 1973).

\section{Bighorn Mountains}

Three possible ages of mafic and ultramafic intrusives are present in the Bighorn Mountains, 3.0, 2.8, and $2.2 \mathrm{Ga}$ (Stueber and others, 1976; Arth and others, 1980). The first two groups were emplaced late in separate plutonicmetamorphic events, while the last was emplaced after significant heating or deformation had ceased. The oldest $(3.0 \mathrm{Ga})$ gneisses in the southern Bighorns contain 1-5 percent amphibolite lenses that may once have been basaltic dikes (Arth and others, 1980; Barker, 1976, 1982). One peridotite has yielded a $K-$ Ar whole-rock date of $3.0 \mathrm{Ga}$ but it is not certain that this is the time of intrusion (Heimlich and Banks, 1968). Other data about mafic bodies of similar age appears to be lacking.

Two generations of generally sheetlike younger mafic bodies have been reported in many areas of the Bighorns since the work of 0sterwald (1955, 1959) but not all mapped rocks have been classiflable (Armbrustmacher, 1977; Barker, 1982). The oldest has generally been described as metadolerite or metabasalt, and what was assumed to be the youngest has generally been described as dolerite, dolerite porphyry, or diabase (Nelson, 1969). Ironically, when the 2.8 and $2.2 \mathrm{Ga}$ ages were quantified (Stueber and others, $1974,1976)$, the $2.8 \mathrm{Ga}$ group contained some dolerites without the meta prefix, apparently indicating that it is possible for some premetamorphic 
dikes to have survived metamorphism unrecrystallized. Dike trend direction and age are not strongly correlated in the Bighorn Mountains; for example, some northwest-trending dikes cut northeast ones while some northeast-trending dikes cut northwest ones in the Cloud Peak primitive area (K1ilsgaard and others, 1972). Mafic dikes commonly cut the gneissic follation of their wall rocks at an angle, but some of the older ones are in turn invaded by the granite they cut, or by aplite or pegmatite (Houston, 1971; Kerr and Langenheim, 1977). Some metadolerite dikes were marginally amphibolitized under water-poor conditions, and both plagioclase and pyroxene in such granoblastic rocks are lower in calcium than in unamphibolitized rocks (Heimlich, Gallagher, and Shotwell, 1974). Because the age of the Late Archean diabases is close to the average $\mathrm{K}-\mathrm{Ar}$ biotite age of $2,730 \mathrm{Ma}$ in the northern Bighorn Mountains, it is thought that emplacement of the dikes coincided closely with uplift and cooling in the northern Bighorn Mountains (Peterman and Houston, in Houston and others, 1988).

The $2.8 \mathrm{Ga}$ dikes include both tholeiltic basalt and ultramafic rocks. Their trends range from $N .30-50^{\circ} \mathrm{E}$. to northwest in the northern part of the range, are east-west and northeast in the central part, and east-west and north-northwest in the southern part of the range (Armbrustmacher, 1972, 1977; Barker, 1982; Heimlich, Nelson, and Gallagher, 1973; Manzer and Heimlich, 1974; Ross and Heimlich, 1972; Stueber, Heimlich, and Ikramuddin, 1974, 1976). Ultramafic rocks are said to be either pre- or post-metamorphism (Heimlich and Banks, 1968). Metapyroxenite is present in two northeasttrending dikes in the northern Bighorns (Manzer and Heimlich, 1974), and hornblendite occurs in the southwestern part (Barker, 1982). A zoned irregularly northeast-trending pre- or synmetamorphic ultramafic pluton $3 \mathrm{~km}$ long is cut by metadolerite and diabase dikes in the southeastern Bighorn Mountains (Luth, 1960; Armbrustmacher, 1972). The pluton consists of pyroxenite and harzburgite in 1 ts northeast half, and grades to slightly younger norite, melanorite, and diorite in its southwest half. Luth (1960) believes that the rocks of this complex at Trallside were intruded as a largely liquid mass, but that bronzite of the ultramafic rocks was regenerated and partially replaced preexisting subcalcic augite during regional almandineamphibolite metamorphism.

The 2.2 Ga mafic intrusives in the Bighorn Mountains consist of dolerite, quartz dolerite, and dolerite porphyry in dikes as long as $20 \mathrm{~km}$ and in $8 \mathrm{mall}$ plutons (0.05 X $0.3 \mathrm{~km}$ ) (Armbrustmacher, 1977; Barker, 1982). The dikes trend east to $\mathrm{N} .20^{\circ} \mathrm{W}$. in the northern Bighorns, northwest and north-northeast to east-northeast in the central mountains, and mainly northwest, northeast, and east in the south (Barker, 1982; Condie and others, 1969b; Heimlich, Nelson and Gallagher, 1973; Killsgaard and others, 1972; Manzer, Helmlich, and Ross, 1971; Nelson, 1969; Ross and Heimlich, 1972; Segerstrom and others, 1976; Stueber, Heiml1ch, and Ikramuddin, 1976). Dolerite porphyry consists of socalled leopard rock having plagloclase-rich flow-differentlated interiors and nonporphyritic contact zones (Heimlich and Manzer, 1973). Rock samples and plagloclase and pyroxene separates from such a dike in the northernmost Bighorns provide close control for the $2.2 \mathrm{Ga} \mathrm{Rb}-\mathrm{Sr}$ isochron (Stueber, Helmlich, and Ikramuddin, 1976, Fig. 4).

\section{Teton Range, Gros Ventre Mountains}

The Rendezvous Metagabbro, a metamorphosed hornblende-plagloclase rock, which includes a plagloclase-rich "leopard diorite" phase, forms a pluton with dimensions greater than $4 \times 8 \mathrm{~km}$ in the southern Teton Range. Together with 
the Webb Canyon (granitic) Gneiss, which is interlayered with flows or s1lls of metabasalt, the Rendezvous Metagabbro has a whole-rock Rb-Sr age of $2,875+150 \mathrm{Ma}$ and was probably removed from the mantle only shortly before a high-grade regional metamorphism of this date (Reed and Zartman, 1973).

Partly altered clinopyroxene-containing tholeiltic diabase, the youngest Precambrian rock in the Teton Range, forms a series of west-northwest-trending dikes as thick as $45 \mathrm{~m}$ and as long as $16 \mathrm{~km}$, and is exposed for a height of over $1500 \mathrm{~m}$. One dike on Mount Moran possesses a K-Ar apparent age of $775+50$ $\mathrm{Ma}$ on its chilled margin, but, because biotite from wall rock $1.5 \mathrm{~m}$ from the dike shows no decrease in age from biotite further away, the dike is believed to have been intruded between 1,360 and $2,570 \mathrm{Ma}$, perhaps just prior to a 1,330-1,500 Ma thermal event (Reed and Houston in Houston and others, 1988; Reed and Zartman, 1972, 1973). However, the paleomagnetic-remanence direction on the Mount Moran dike is essentially identical with that of similar-aged $(0.7 \mathrm{Ga})$ rocks from the Beartooth Mountains, Montana (Larson and others, 1974).

Precambrian gneisses exposed in the Gros Ventre Mountains contain small lenses of serpentinite and hornblende-clinopyroxene gabbro and are cut by widely scattered pre-granite diabase dikes (Simons and others, 1981).

\section{Wind River Range}

Although radiometric dating is very spotty, there seem to be at least three and perhaps four ages of mafic-ultramafic intrusive events recorded in the Wind River Range: $>3.2 \mathrm{Ga}$ (Middle? Archean), $2.8 \mathrm{Ga}$ (Late Archean), and one or more events from 1.7-2.1 Ga in the Early Proterozoic. All three events produced both tholeitic basalt and ultramafic rocks, and they are interspersed with two granulite-facies metamorphic events (Aleinikoff and others, 1987).

The age of the oldest mafic-ultramafic igneous event at $>3.2$ Ga is based on the observation that a 5-km east-trending belt of metaharzburgite and metapyroxenite near Horseshoe Lake in the north-central Wind Rivers (Link and Bronson, 1984; Worl and others, 1986) was intruded before the first of two regional granulite-facies metamorphic events (Anderson, 1985), and on the dating of that earliest granulite event as $3.2 \mathrm{Ga}$ (Aleinikoff and others, 1987). Rocks of this belt are agmatized and locally invaded by pegmatitic dikes (Anderson, 1985; Worl and others, 1986). Other rocks that may be related to the oldest group are: 1) Irregular dike-like bodies of clinopyroxene-containing metagabbro and metadiorite, which occur in two northwest-trending zones 8.5 and $39 \mathrm{~km}$ long in the northwestern Wind Rivers, and were mapped as Archean (Worl and others, 1986); 2) Premetamorphic ultramafic bodies in the northwestern Wind Rivers that may have been tectonically emplaced (Frost, 1971) or in the central Wind Rivers that may be preserved mantle beneath the Archean crust (Frost and Worl, 1983); 3) Thin layers of pre-early-folding serpentinite and a pluton of post-early-folding pre-late-folding two-pyroxene granulite in the northeastern Wind Rivers (Perry, 1965); and 4) Melanosomes of regional migmatites throughout the range (Stuckless and others, 1985).

The Late Archean mafic-ultramafic intrusive event is justified by relations of greenstone-belt rocks in the southern Wind Rivers, which must be older than the $2.63 \mathrm{Ga}$ Louis Lake batholith that intrudes it (Stuckless and others, 1985); part of this belt has been dated by the Rb-Sr whole-rock method as $2.8 \mathrm{Ga}$ (Z.E. Peterman in Stuckless and others, 1985, p. 852). The Rb-Sr dated part consists of greenschist facies turbidites and calc-alkaline meta- 
andesites that are sutured to a tholeific part of the belt containing ultramafic rocks, metagabbro, metadiabase, and pillow lavas (Bayley, 1963, 1965; Bayley, Proctor, and Condie, 1973), which may represent an ophiolitic oceanic crust (Condie, 1972; G.D. Harper, 6/6/86 written communication). Other metagabbros cut by diabase dikes elsewhere in the range (Oftedah1, 1953; Granger and others, 1971; Worl and others, 1984) could be part of the $2.8 \mathrm{Ga}$ Intrusive sequence.

The Early Proterozoic (multi?) event consists of unmetamorphosed or mildly metamorphosed sheet-like diabase and ultramafic dikes that trend mainly northeast in a southern, a central, and a northern swarm; a few trend northwest (Granger and others, 1971; Pearson and others, 1971; Wor1, 1963a and b; Worl and others, 1986). Diabase dikes are as long as $32 \mathrm{~km}$; one sheet of feldspathic peridotite with the composition of an olivine websterite is as long as $13 \mathrm{~km}$ (Pearson and others, 1971). K-Ar whole-rock ages have been measured in the southern diabase swarm by Condie and others (1969b) who thought there were two Wind River events at $1.4-1.8 \mathrm{Ga}$ and 1.9-2.2 $\mathrm{Ga}$. Their oldest whole-rock dates, 1,890 and $2,060 \mathrm{Ma}$, we re determined for two 3 to $6-\mathrm{km}$ dike segments along the Sweetwater River in the southernmost part of the range. Spall (1971) found that replicate $\mathrm{K}$-Ar pyroxene ages on three dikes northwest of Atlantic City [with $\mathrm{K}-\mathrm{Ar}$ whole-rock ages of 1.3-1.5 Ga (Condie and others, 1969b)] fell in the range 1.7-1.9 Ga, indicating intrusion at a minimum of $1.9 \mathrm{Ga}$. Thus it is unclear from the $\mathrm{K}$-Ar dating whether there are one or more late mafic intrusive events. However, in the northern Wind Rivers, Worl (1967, 1968, 1969, 1972) reports several generations of metadiabasic intrusives, and Granger and others (1971) recognize three types of diabase, the oldest of which was metamorphosed. The post-metamorphic types include both labradorite glomeroporphyry and equigranular diabase, the latter possibly the younger of the two types.

\section{Ow1 Creek Mountains}

Two groups of Archean and one group of Early Proterozoic(?) tholeiftic intrusives are probably present in the Owl Creek Mountains. The oldest are orthoamphibolite layers in supracrustal assemblages exposed in Wind River Canyon and in the Copper Mountain area, some of which were gabbroic sills (Condie, 1967, p. 128; Granath, 1975, p. 80; Hausel and others, 1985, p. 5, 7); these are older than $2.7 \mathrm{Ga}$, based on Giletti and Gast's (1961) Rb-Sr ages on minerals from crosscutting pegmatites. A younger group of mapped Archean dikes and sills occurs in two sets in the Copper Mountain area, one eastnortheast-trending parallel to the strike of the metasedimentary units, the other northwest- to west-northwest-trending across the older orthoamphibolites In the central and south-central parts of the area (Thaden, $1980 \mathrm{a}, \mathrm{b}, \mathrm{c}$ ); both sets are amphibolitized and are shown as cut by numerous apophyses of Archean granite, but they are not otherwise quantitatively dated (Hausel and others, 1985, pl. 1). Early Proterozolc(?) dikes have been studied in both the Merritt Pass area and the Copper Mountain area. In the Merritt Pass area they consist of melaamphibolite in a consistently west-northwest- to west-trending owarm; five of these have ylelded 1.9-2.1 Ga K-Ar whole-rock ages (Condie and others, 1969b). Proterozolc(?) dikes in the Copper Mountain area are unmetamorphosed clinopyroxene-containing basalt in two sets, one north- to east-northeast-trending in the, eastern part of the area, the other northeasttrending in the south-central part of the area; they are presumed to be dated by the Merritt Pass numbers. Although no intersections are mapped between the Proterozoic(?) basalt and the next-older amphibolite dikes in the Copper 
Mountain area, the former cleanly cut the Archean granite that sent apophyses through the latter; the Proterozolc basalts are cut by cupriferous quartz veins (Hausel and others, 1985, pls. 1, 2, fig. 3).

The area known variously as eastern Owl Creek Mountains, southern Bighorn Mountains, or Badwater uplift contains two ages of mafic intrusives, some pre$2.75 \mathrm{Ga}$ premetamorphic prefolding amphibolite sills, and younger but undated sparse discordant diabase dikes that are concentrated along the eastern border of the outcrop area (Gard, 1969). Two sets of these diabase dikes are mapped in the northeast part of the area; one set trends northwest to west-northwest, the other northeast to north-northeast; no intersections are mapped between any dikes of the two sets. These dikes were intruded between $F_{1}$ and $F_{2}$ fold deformations (Wells, 1975).

Granite Mountains, Seminoe Mountains, Ferris Mountains, Casper Mountain, and northern Laramie Mountains

Two generations of Late Archean tholeiftic intrusives have been recognized in the Granite Mountains: 1) Unmapped discordant metaamphibolite and serpentinite that must have been emplaced prior to or during a $2.9 \mathrm{Ga}$ regional metamorphism; these were followed by a $2.6 \mathrm{Ga}$ granite; 2) Mapped northeast- or east-northeast-trending diabase dikes and nephrite veins emplaced shortly after intrusion of the $2.6 \mathrm{Ga}$ granite. The younger diabase dikes have chill zones and can be traced for distances as great as $5 \mathrm{~km}$. Some are fresh and unmetamorphosed while some are deuterically altered, but it is not known whether they are all of the same age (Peterman and others, 1971; Peterman and Hildreth, 1978; Stuckless and others, 1977, 1981; Stuckless and Peterman, 1977).

Several sets of undated mafic-ultramafic dikes as long as $2 \mathrm{~km}$ are present in the Archean rocks of the Seminoe and Ferris Mountains. 01der ( $>2.7$ Ga) metagabbro sills and minor serpentinite are cut by a swarm of northeastto east-trending dikes of diabase and "leopard rock" porphyritic gabbro in the Bradley Peak area (Bayley, 1968; Klein, 1982a, and b). The youngest Precambrian rock units in the area of Kortez Dam are north-northeast-trending partly altered diabase dikes (Dixon, 1982, 1988). Two sets of northnorthwest- and north-northeast-trending Precambrian mafic dikes are present in the Ferris Mountains, an early set of fine-grained basalt and a later set of hornblende diorite or gabbro. The later dikes are more coarsely crystalline but are generally chloritized or saussuritized; some are cut by thin granite pegmatites (H.R. Dixon, 1984 written communication; M.W. Reynolds, 1985 written communication).

Two or three main generations of indirectly dated mafic-ultramafic Intrusives are recognized on Casper Mountain and in the northern Laramie Mountains to the east of Casper Mountain. On Casper Mountain there are thought to be two Archean generations and one Proterozoic one, as follows: 1) Pre-amphibolite-grade metamorphism (pre $2.8 \mathrm{Ga}$ ) mafic dikes and sills, now pods as long as $50 \mathrm{~m}$; 2) Post-deformation pre-granite emplacement of, first, ultramafic magma, and, second, porphyritic diabase ("leopard rock"); a 2.4-2.6 Ga granite was accompanied by a late stage of regional metamorphism, or a econd lower-grade metamorphism; 3) Unmetamorphosed north-northeast- to-easttrending clinopyroxene-contalning diabase, and rhyolite, dikes as long as $4 \mathrm{~km}$ (some post 1.6-1.7 Ga?); In some locallties young diabase dikes cut across other diabase dikes (Burford and others, 1979; Eller and Friberg, 1982; Gable and Burford, 1982; Gable and others, 1988). Several generations of Precambrian mafic-ultramafic intrusives are mapped in the northern Laramie 
Mountains east of Casper Mountain: 0lder altered northeast- and northwest- to west-trending ultramafic rocks and metadiabases (some with garnet) are cut by northeast- to east-trending vertical locally-composite diabase dikes as long as $3 \mathrm{~km}$ (Gable, 1987; Johnson and Hills, 1976).

\section{Summary}

Mafic and ultramafic magmas representing melt samples of an inhomogeneous lower crust and upper mantle have been sparsely to voluminously intruded through the Archean core of western America throughout a span of Precambrian time representing half of the Earth's history. The greatest mass of the Intruded magmas was tholeific basalt, now diabase of various types, whose time of intrusion was apparently spread out over the entire recorded Precambrian. More primitive tholeiltes are represented in nearly all exposures and at all times while more differentiated alkalic olivine dolerites, quartz dolerites, or suites containing magmas as siliceous as quartz porphyry rhyolite are generally restricted to Middle and Late Proterozoic time mainly in northwesterly swarms near the southeastern and northwestern margins of the Archean craton. Plagloclase-porphyritic (leopard rock) diabases are present in many mountain ranges; the evidence shows that they are somewhat older than accompanying nonporphyritic diabases in the Wind River Range and central Laramie Mountains. Ultramafic intrusives form only 5 percent or less of the mapped intrusives (none in the Belt basin), are temporally restricted to the older rocks, and may have been formed in a variety of ways: As oceanic or ophiolitic basement (Wind River Range), as liquid intrusives derived from depths (all ranges), as solid or semi-solid intrusives (locally in Wind River Range or Tobacco Root Mountains), as differentiates of noritic intrusives at the level where they eventually cooled (locally in the Black Hills, central Laramie Mountains, Park Range, and Beartooth Mountains). Ultramafic intrusives, particularly the older ones, frequently occupy more equant or lens-like bodies (although sheet-like ultramafic intrusives occur in the central Wind River Range and northern Bighorns) while the tholeiitic basalts invariably form single or multiple sheet-like bodies that, where the swarms are voluminous, may expand their country rocks as much as a third. A few plutons of batholith size occur, principally the Stillwater, Lake Owens, and Mullen Creek complexes, the Rendezvous Metagabbro, and the gabbro of Elkhorn Mountain. All of these, except the Rendezvous, have been postulated to have formed by multiple intrusion of a variety of magmatic liquids.

Unraveling the tectonic, metamorphic, and magmatic histories has just begun. Most dike swarms with consistent trend orlentation would be considered by many as prima facie evidence for a preserved tensional environment. This might be disputed, however, where plutons and some dike swarms have been considered to be the underpinnings of former accreted volcanic arcs, as along the Cheyenne Belt at the southeast cratonic margin (F1g. 2). Further difficulties are introduced where trend patterns are more complex, as in the north and northwest parts of the Archean craton. Furthermore, the dated episodes of basaltic dike intrusion are interspersed throughout the area in complex fashion with repeated episodes of metamorphism, deformation, and the emplacement of synorogenic granitold plutons, all of which are normally interpreted as synomous with compression or shearing. Even though much work remains to be done on precise radiometric geochronology in the Wyoming Province, it seems obvious that additional knowledge will help to understand its complex tectonic history, not simplify it. 
Correlation between times of dike intrusion in the Canadian Shield and the Wyoming Province is less than impressive (Fig. 6). The Grenville (575 $\mathrm{Ma})$, Franklin $(750 \mathrm{Ma})$, Mackensie $(1,220 \mathrm{Ma})$, Priessac $(2,140 \mathrm{Ma})$, and Matachewan $(2,600 \mathrm{Ma})$ dike swarms, which together account for four fifths of the shield dikes, are underrepresented or absent in the Wyoming Province, while dike events near $1.45 \mathrm{Ga}$ or $>2.65 \mathrm{Ga}$, important in Wyoming, are absent in Canada. What this means is that whatever it takes tectonically to generate a dike swarm was applied on a scale less than the size of present North America.

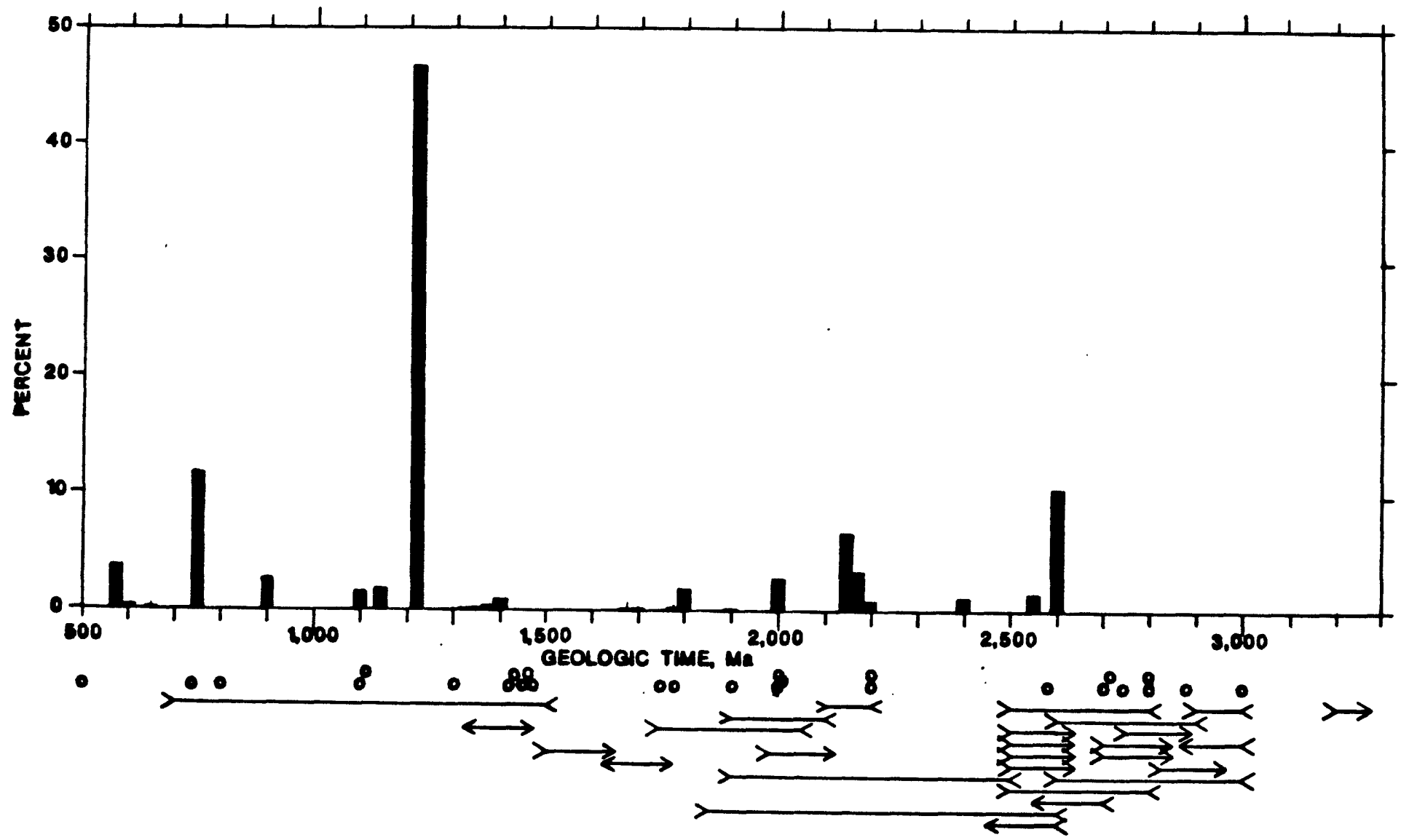

Figure 6. Comparison of dated Precambrian mafic dike intervals in the Canadian Shield and Wyoming Province. For the Canadian Shield dike intervals height of bars is proportional to volume of dikes mapped, as derived from Fahrig and West (1986). For the Wyoming Province the same geologic time abscissa applies, but data are lacking for compiling a similar ordinate. Well-constrained Wyoming Province dike ages are shown with circles; less wellconstrained ones are indicated with arrows, which are constrained at arrow hafts but unconstrained at arrow heads (see Figs. 1, 2, and text). 


\section{References cited}

Aadland, R.K., and E.H. Bennett (1979) Geologic map of the Sandpoint quadrangle, Idaho and Washington: Idaho Bureau of Mines and Geology Geologic Map Series, scale 1:250,000.

Aleinlkoff, J.N., I.S. Williams, W. Compston, J.S. Stuckless, and R.G. Worl (1987) Conventional and ion microprobe $\mathrm{U}-\mathrm{Pb}$ ages of Archean rocks from the Wind River Range, Wyoming: Geological Society of America Abstracts with Programs 19, no. 7, 569.

Anderson, C.I. (1987) Petrography and geochemistry of Archean pyroxenites, Horseshoe Lake quadrangle, Wind River Mtns., Wyoming: Geological Society of America Abstracts with Programs 17, no. 4, 206.

Armbrustmacher, T.J. (1972) Mafic dikes of the Clear Creek drainage area, southeastern Bighorn Mountains, Wyoming: University of Wyoming Contributions to Geology 11, no. 1, 31-40.

Armbrustmacher, T.J. (1977) Geochemistry of Precambrian mafic dikes, central Bighorn Mountains, Wyoming, U.S.A.: Precambrian Research 4, 13-38.

Armstrong, R.L., and F.A. Hills (1967) Rb-Sr and K-Ar geochronologic studies of mantled gneiss domes, Albion Range, southern Idaho, U.S.A.: Earth and Planetary Science Letters 3, 114-124.

Arth, J.G., F. Barker, and T.W. Stern (1980) Geochronology of Archean gneisses in the Lake Helen area, southwestern Big Horn Mountains, Wyoming: Precambrian Research 11, 11-22.

Baadsgaard, H. and P.A. Mueller (1973) $\mathrm{K}-\mathrm{Ar}$ and $\mathrm{Rb}-\mathrm{Sr}$ ages of intrusive Precambrian mafic rocks, southern Beartooth Mountains, Montana and Wyoming: Geological Society of America Bulletin 57, no. 6, 3535-3644.

Barker, F. (1976) Archean sequence of the southwestern Big Horn Mountains, Wyoming: Geological Society of America Abstracts with Programs 8, no. 5, 568.

Barker, F. (1982) Geologic map of the Lake Helen quadrangle, Big Horn and Johnson Counties, Wyoming: U.S. Geological Survey Geologic Quadrangle Map GQ-1563, scale $1: 24,000$.

Bayley, R.W. (1963) A preliminary report on the Precambrian 1ron deposits near Atlantic City, Wyoming: U.S. Geological Survey Bulletin 1142-C, 1-21.

Bayley, R.W. (1965) Geologic map of the Miners Delight quadrangle, Fremont County, Wyoming: U.S. Geological Survey Geologic Quadrangle Map GQ-460, scale $1: 24,000$.

Bayley, R.W. (1968) Geologic map of the Bradley Peak quadrangle, Carbon County, Wyoming: U.S. Geological Survey Geologic Quadrangle Map GQ-773, scale $1: 24,000$.

Bayley, R.W., P.D. Proctor, and K.C. Condie (1973) Geology of the South Pass area, Fremont County, Wyoming: U.S. Geological Survey Professional Paper 793, $1-39$.

Becraft, G.E., J.A. Calkins, E.C. Pattee, R.D. Weldin, and J.M. Roche (1966) Mineral resources of the Spanish Peaks primitive area, Montana: U.S. Geological Survey Bulletin 1230-B, 1-45.

Berg, R.B. (1979) Talc and chlorite deposits of Montana: Montana Bureau of Mines and Geology Memolr 45, 1-66.

B1shop, D.T. (1973) Petrology and chemistry of the Purcell 81118 in Boundary County, Idaho: Belt Symposium II, Sept. 17-22, 1973, Moscow, Idaho sponsored by Department of Geology, University of Idaho and Idaho Bureau of Mines and Geology, 15-66.

Bow, C., D. Wolfgram, A. Turner, S. Barnes, J. Evans, M. Zdepsk1, and A. Boudreau (1982) Investigations of the Howland Reef of the Stiliwater 
Complex, Minneapolis adit area--stratigraphy, structure, and

mineralization: Economic Geology 77, no. 6, 1481-1492.

Brookins, D.G. (1968) Rb-Sr and K-Ar age determinations from the Precambrian rocks of the Jardine-Crevice Mountain area, southwestern Montana: Wyoming Geological Association Earth Science Bulletin 1, no. 2, 5-9.

Bryant, B. (1980) Metamorphic and structural history of the Farmington Canyon Complex, Wasatch Mountains, Utah: Geological Society of America Abstracts with Programs 12, no. 6, 269.

Bryant, B. (1984) Reconnalssance geologic map of the Precambrian Farmington Canyon Complex and surrounding rocks in the Wasatch Mountains between Ogden and Bountiful, Utah: U.S. Geological Survey Miscellaneous Investigations Map I-1447, scale $1: 50,000$.

Bryant, B. (In press 1988) Geology of the Farmington Canyon Complex, Wasatch Mountains, Utah: U.S. Geological Survey Professional Paper 1476, 48 galley P., Plate 1 scale $1: 50,000$.

Bryant, B., and P. Graff (1980) Metalgneous rocks on Antelope Island, Great Salt Lake, Utah: Geological Society of America Abstracts with Programs 12, no. 6,269 .

Burford, A.E., R.G. Corbett, P.C. Franks, L.M. Friberg, R.C. Lorson, F.A. Marsek, R.F. Nanna, J.C. Schumacher, and R.E. Wyner (1979) Precambrian complex of Casper Mountain, Wyoming--A preliminary paper: Wyoming Geological Association Earth Sciences Bulletin 12, no. 2, 58-69.

Casella, C.J. (1969) A review of the Precambrian geology of the eastern Beartooth Mountains, Montana and Wyoming: Geological Soclety of America Memoir 115, 53-71.

Casella, C.J. (1979) The geology of the southwestern Beartooth Mountains, Yellowstone National Park, Montana and Wyoming: Guide to the Precambrian rocks of the Beartooth Mountains (1979 Field Conference of the Archean Geochemistry Working Group, IGCP), University of Florida, Gainesville, 5-9.

Casella, C.J., J. Levay, E. Eble, B. Hirst, K. Huffman, V. Lahti, and R. Metzger (1982) Precambrian geology of the southwestern Beartooth Mountains, Yellowstone National Park, Montana and Wyoming in Precambrian geology of the Beartooth Mountains, Montana and Wyoming: Montana Bureau of Mines and Geology Special Publication 84, 1-24.

Catanzaro, E.J. (1967) Correlation of some Precambrian rocks and metamorphic events in parts of Wyoming and Montana: The Mountain Geologist 4, no. 1, 9-14.

Catanzaro, E.J., and J.L. Rulp (1964) Discordant zircons from the Little Belt (Montana), Beartooth (Montana), and Santa Catalina (Arizona) Mountains: Geochimica et Cosmochimica Acta 28, no. 1, 87-124.

Clark, M.L., and D.W. Mogk (1985) Development and significance of the Blacktail Mountains Archean metamorphic complex, Beaverhead County, Montana: Geological Society of America Abstracts with Programs 17, no. 4, 212.

Compton, R.R. (1980) Fabrics and strains in quartzites of a metamorphic core complex, Raft River Mountains, Utah: Geological Society of America Memoir $153,385-398$.

Condie, K.C. (1967) Petrologic reconnalssance of the Precambrian rocks in Wind River Canyon, central Owl Creek Mountains, Wyoming: University of Wyoming Contributions to Geology 6, no. 2, 123-129.

Condie, K.C. (1972) A plate tectonics evolutionary model of the South Pass Archean greenstone belt, southwestern Wyoming: 24th International

Geological Congress, Section 1, 104-112.

Condle, K.C., C.K. Barsky, and P.A. Mueller (1969a) Geochemistry of 
Precambrian diabase dikes from Wyoming: Geochimica et Cosmochimica Acta 33, no. $11,1371-1388$.

Condie, R.C., A.P. Leech and H. Baadsgaard (1969b) Potassium-Argon ages of Precambrian mafic dikes in Wyoming: Geological Society of America Bulletin, 8, no. 5, 899-906.

Cressman, E.R. (1985) The Prichard Formation of the lower part of the Belt Supergroup (Middle Proterozolc), near Plains, Sanders County, Montana: U.S. Geological Survey Bulletin 1553, 1-64.

Cressman, E.R., and J.E. Harrison (1986) Geologic map of the Yaak River area, Lincoln County, northwest Montana: U.S. Geological Survey Miscellaneous Field Studies Map MF-1881, scale $1: 48,000$.

Crittenden, M.D., Jr., C.A. Wallace, and M.J. Sheridan (1967) Mineral resources of the High Uintas Primitive Area, Utah: U.S. Geological Survey Bulletin 1230-I, 1-27.

Czamanske, G.K., and M.L. Zientek, editors (1985) The St1llwater Complex, Montana: Geology and guide: Montana Bureau of Mines and Geology Special Publication 92, 1-396.

Davis, P.A., Jr., A.M. Stueber, and M.J. Potts (1977) Rb and Sr concentrations and $\mathrm{Sr}$ isotope ratios in the Preacher Creek ultramafic intrusion, Wyoming: University of Wyoming Contributions to Geology 15, no. 1, 17-25.

DePaolo, D.J., and G.J. Wasserburg (1979) Sm-Nd age of the Stillwater Complex and the mantle evolution curve for neodymium: Geochimica et Cosmochimica Acta 43, 999-1008.

Desmarais, N.R. (1981) Metamorphosed Precambrian ultramafic rocks in the Ruby Range, Montana: Precambrian Research 16, 67-101.

Dewitt, E.J., J.A. Redden, A.B. Wilson, and D. Buscher (1986) Mineral resource potential and geology of the Black Hills National Forest, South Dakota and Wyoming: U.S. Geological Survey Bulletin 1580, 135 p.

Dixon, H.R. (1982) Archean granitic rocks in the Seminoe Mountains, Wyoming, in S.S. Goldich, chairperson; 1982 Archean Geochemistry Field Conference, August 15-19, 1982, Seminoe Mountains and Hartville Uplift, Wyoming; part 1, Guide to Field Trips, 50-63.

Dixon, H.R. (In press 1988) Geology of the Seminoe Dam NE quadrangle, Carbon County, Wyoming: U.S. Geological Survey Geologic Quadrangle Map GQscale, $1: 24,000$.

Divis, A.F. (1973) Geochronology of the Sierra Madre Range, Wyoming: EOS (Trans. of AGU) 54, 1226.

Divis, A.F. (1976) Geology and geochemistry of Sierra Madre Range, Wyoming: Quarterly of the Colorado School of Mines, 71, no. 3, 1-127.

Dudas, F.O., and D.H. Eggler (1986) Mantle xenoliths from the Crazy Mountains, Montana: Geological Society of America Abstracts with Programs 18, no. 6, 588.

Ecklemann, F.D. and A. Poldervaart (1957) Geologic evolution of the Beartooth Mountains, Montana and Wyoming-Part 1, Archean history of the Quad Creek area: Geological Society of America Bulletin 68, no. 10, 1225-1262.

Edwards, J.S. (1981) The petrology and contact relationships of the couthwestern portion of the Precambrian Mullen Creek maflc complex, Medicine Bow Mountains, Wyoming: Geological Society of America Abstracts with Programs 13, no. 4, 195.

Eggler, D.H. (1987) Geochemistry of upper mantle and lower crust beneath Colorado and Wyoming: Geological Soclety of America Abstracts with Programs 19 , no. $5,272,273$.

Eller, J.A., and L.M. Friberg (1982) Petrology of amphibolites on Casper Mountain, Wyoming: Geological Soclety of America Abstracts with Programs 
14, no. 6, 310 .

Elllott, J.E., D.L. Gaskill, and W.H. Raymond (1983) Geological and geochemical investigations of the North Absaroka Wilderness Study Area, Park and Sweetgrass Countles, Montana: U.S. Geological Survey Bulletin 1505-A, $1-251$.

Erslev, E.A. (1981) Petrology and structure of the Precambrian metamorphic rocks of the southern Madison Range, southwestern Montana: Cambridge, Massachusetts, Harvard University, Ph.D. thesis, 1-133.

Erslev, E.A. (1983) Pre-Beltian geology of the southern Madison Range, southwestern Montana: Montana Bureau of Mines and Geology Memoir 55, 1-26.

Evans, K.V. (1986) Middle Proterozolc deformation and plutonism in Idaho, Montana, and British Columbia in Belt Supergroup: A guide to Proterozolc rocks of western Montana and adjacent areas: Montana Bureau of Mines and Geology Special Publication 94, 237-244.

Fahrig, W.F., and T.D. West (1986) Diabase dyke swarms of the Canadian Shield: Geological Survey of Canada, Map 1627A, scale 1:4,873,900 (approx.).

Ferris, C.S., Jr. and H.W. Kreuger (1964) New radiogenic dates on Igneous rocks from the southern Laramie Range, Wyoming: Geological Society of America Bulletin 75, 1051-1054.

Fraser, G.D., H.A. Waldrop, and H.J. Hyden (1969) Geology of the Gardiner area, Park County, Montana: U.S. Geological Survey Bulletin 1277, 1-118.

Frost, B.R. (1971) Geology of the Double Lake area, Wind River Mountains, Fremont County, Wyoming: University of Washington (Seattle) M.S. thesis, 153.

Frost, B.R., and R.G. Worl (1983) Evidence for Early Precambrian mafic crust in the central Wind River Mountains, Wyoming: Geological Soclety of America Abstracts with Programs 15, no. 5, 423.

Gable, D.J. (1987) Geologic maps of greenstone-granite areas, northern Laramie Mountains, Converse and Natrona Counties, Wyoming: U.S. Geological Survey Miscellaneous Investigations Series Map I-1724, scale 1:24,000.

Gable, D.J., and A.E. Burford (1982) Map of the Precambrian geology of Casper Mountain, Natrona County, Wyoming: U.S. Geological Survey Open-File Report OF 82-67.

Gable, D.J., A.E. Burford, and R.G. Corbett (In press 1988), The Precambrian geology of Casper Mountain, Natrona County, Wyoming: U.S. Geological Survey Professional Paper 1460, 42 galley p., Plate 1 scale 1:20,000.

Gard, T.M., (1969) Tectonics of the Badwater uplift area, central Wyoming: University Park, Pennsylvania, Pennsylvania State University Ph.D. thesis, $1-144$.

Garihan, J.M. (1979) Geology and structure of the central Ruby Range, Madison County, Montana: Geological Society of America Bulletin 90, part I, 323326.

Gilett1, B.J. (1966) Isotopic ages from southwestern Montana: Journal of Geophysical Research 71, no. 16, 4029-4036.

Gilett1, B.J., and P.W. Gast (1961) Absolute age of Precambrian rocks in Wyoming and Montana: New York Academy of Sclence Annals 91, 454-458.

Granath, J.W., 1975, Wind River Canyon--An example of a greenstone belt in the Archean of Wyoming, U.S.A.: Precambrian Research 2, 71-91.

Granger, H.C., E.J. McKay, R.E. Mattick, L.L. Patten, and P. McIlroy (1971) Mineral resources of the Glacier Primitive Area, Wyoming: U.S. Geological Survey Bulletin 1319-F, 1-113.

Griggs, A.B. (1973) Geologic map of the Spokane quadrangle, Washington, Idaho, and Montana: U.S. Geological Survey Miscellaneous Geologic Investigations Map I-768, scale 1:250,000. 
Hadley, J.B. (1969) Geologic map of the Varney quadrangle, Madison County, Montana: U.S. Geological Survey Geologic Quadrangle Map GQ-814, scale $1: 62,500$.

Hall, R.P., D.J. Hughes, C.R.L. Frlend, and G.L. Snyder (1987) Proterozolc mantle heterogeneity: geochemical evidence from contrasting basic dykes Pharaoh, T.C., Beckinsale, R.D., and Rickard, D. (editors), Geochemistry and mineralization of Proterozoic volcanic suites: Geological Society of London Special Publication 33, 9-21.

Hansen, W.R. (1965) Geology of the Flaming Gorge area, Utah-ColoradoWyoming: U.S. Geological Survey Professional Paper 490, 1-196.

Harper, G.D., and P.K. Link (1986) Geochemistry of Upper Proterozoic riftrelated volcanics, northern Utah and southeastern Idaho: Geology 14, 864867.

Harrison, J.E. (1972) Precambrian Belt Basin of northwestern United States: Its geometry, sedimentation and copper occurrences: Geological Society of America Bulletin 83, 1215-1240.

Harrison, J.E., E.R. Cressman, and J.W. Whipple (1983) Preliminary geologic map of part of the Kalispeli $1^{\circ} \times 2^{\circ}$ quadrangle, Montana: U.S. Geological Survey Open-File Report 83-502, scale 1:250,000.

Harrison, J.E., E.R. Cressman, and M.D. Klelnkopf (1985) Regional structure, the Atlantic Richfield-Marathon $0 i l$ No. 1 Gibbs borehole, and hydrocarbon resource potential west of the Rocky Mountain trench in northwestern Montana: U.S. Geological Survey Open-File Report 85-249, 1-8.

Harrison, J.E., A.B. Griggs, and J.D. Wells (1986) Geologic and structure maps of the Wallace $1^{\circ} \times 2^{\circ}$ quadrangle, Montana and Idaho: U.S. Geological Survey Miscellaneous Investigations Series Map I-1509-A2, scale 1:250,000.

Harrison, J.E., and Z.E. Peterman (1984) Introduction to correlation of Precambrian rock sequences. Correlation of Precambrian rocks of the United States and Mexico: U.S. Geological Survey Professional Paper 1241-A, A1-A7.

Hause1, W.D., P.J. Graff, and K.G. Albert (1985) Economic geology of the Copper Mountain supracrustal belt, Owl Creek Mountains, Fremont County, Wyoming: The Geological Survey of Wyoming Report of Investigations 28, 133.

Hearn, B.C., and E.S. McGee (1987) Crust and upper mantle beneath the northern plains: Evidence from Montana xenoliths: U.S. Geological Survey Circular 956, 32-34.

Hedge, C.E., J.S. Stacy, and B. Bryant (1983) Geochronology of the Farmington Canyon Complex, Wasatch Mountains, Utah, in Tectonic and stratigraphic studies in the northeastern Great Basin, D.M. Miller, K.A. Howard, and V.R. Todd, eds.: Geological Society of America Memoir 157, 37-44.

Heimlich, R.A., and P.0. Banks (1968) Radiometric age determinations, Bighorn Mountains, Wyoming: American Journal of Science Letters 266, no. 3, 180192.

Heimlich, R.A., G.L. Gallagher, and L.B. Shotwell (1974) Quantitative petrography of mafic dikes from the central Bighorn Mountains, Wyoming: Geological Magazine 111, no. 2, 97-107.

Heimlich, R.A., and G.K. Manzer, Jr. (1973) Flow differentiation within leopard rock dikes, Bighorn Mountains, Wyoming: Earth and Planetary Science Letters 17, 350-356.

Heimlich, R.A., G.C. Nelson, and G.L. Gallagher (1973) Metamorphosed mafic dikes from the southern Bighorn Mountains, Wyoming: Geological Society of America Bulletin 84, 1439-1450.

Heinrich, E.W. (1960) Pre-Beltian geology of the Cherry Creek and Ruby Mountains areas, southwestern Montana: Montana Bureau of Mines and Geology 
Memoit $38,15-40$.

Helz, R.T. (1985) Compositions of fine-grained mafic rocks from sills and dikes associated with the Stillwater Complex: Montana Bureau of Mines and Geology Special Publication 92, 97-117.

Helz, R.T. (1987) Evidence for melt extraction from the sills and dikes associated with the Stillwater Complex, Montana: Geological Society of America Abstracts with Programs 19, no. 7, 699.

Hobbs, S.W., editor (1983) Guide to field trips, Belt Symposium II, Department of Geology, University of Montana, Missoula, Montana, 1-124.

Holden, G.S., and G.L. Snyder (1983) Compositional variation of mafic rocks from an Archean granite-greenstone terrane, central Laramie Range, Wyoming: Geological Society of America Abstracts with Programs 15, no. 5, 423.

Houston, R.S. (1971) Regional tectonics of the Precambrian rocks of the Wyoming Province and its relationship to Laramide structure: Wyoming Geological Association Guidebook, 19-27.

Houston, R.S., and others (1968) (second printing 1978), A regional study of rocks of Precambrian age in that part of the Medicine Bow Mountains lying in southeastern Wyoming--with a chapter on the relationship between Precambrian and Laramide structure: The Geological Survey of Wyoming Memoir 1, 1-167.

Houston, R.S. and B.E. Ebbett (1977) Geologic map of the Sierra Madre and western Medicine Bow Mountains, southeastern Wyoming: U.S. Geological Survey Miscellaneous Field Series Map MF-827, scale $1: 125,000$.

Houston, R.S., and K.E. Karlstrom (1979) Uranium-bearing quartz-pebble conglomerates: Exploration model and United States resource potential: U.S. Department of Energy Open-File Report GJBX-1 (80), 1-510.

Houston, R.S. and C.J. Orback (1976) Geologic map of the Lake Owen quadrangle, Albany County, Wyoming: U.S. Geological Survey Geologic Quadrangle Map GQ1304 , scale $1: 24,000$.

Houston, R.S., J.C. Reed, Jr., K.E. Karlstrom, E.A. Erslev, G.L. Snyder, R.G. Worl, B. Bryant, M.W. Reynolds, Z.E. Peterman, N.J. Page, M.L. Zientek, and C.D. Frost (in press 1988) The Wyoming Province, Chapter III, in

Precambrian, Conterminous United States, edited by J.C. Reed, Jr., L.T. Silver, P.K. Sims, D.W. Rankin, R.S. Houston, and M.W. Reynolds, volume C-2 of Geology of North America: Geological Society of America Decade of North American Geology, 62 proof pages.

Hoy, T. (1979) Geology of the Estella-Kootenay King area, Hughes Range, southeastern British Columbia: British Columbia Ministry of Energy, Mines and Petroleum Resources Preliminary Map 36, scale 1:50,000.

Hoy, T. (1984) Geology of the Cranbrook sheet and Sullivan Mine area: British Columbia Ministry of Energy, Mines and Petroleum Resources Preliminary Map 54, scale $1: 50,000$.

Hby, T. (1985) The Purcell Supergroup, Fernie west-half, southeastern British Columbia; Part A-Stratigraphy-Measured sections: British Columbia Ministry of Energy, Mines and Petroleum Resources Bulletin 76, 1-79.

Hby, T. and L. Diakow (1982) Geology of the Moyle Lake area: Province of British Columbia Preliminary Map 49, scale 1:50,000.

Bunt, G. (1962) Time of Purcell eruption in southeastern British Columbia and southwestern Alberta: Journal of the Alberta Soclety of Petroleum Geologists 10, no. 7, 438-442.

Irvine, T.N., D.W. Keith, and S.G. Todd (1982) Formation of the St11lwater J-M reef by concurrent fractional crystallization and liquid mixing in a stratified magma body: 1981-1982 Annual Report of the Director, Geophysical Laboratory, No. 1880 (reprinted from Carnegie Institution of Washington 
Yearbook 81), 286-294.

James, H.L. (1946) Chromite deposits near Red Lodge, Carbon County, Montana: U.S. Geological Survey Bulletin 949-F, 151-189.

James, H.L., and C.E. Hedge, (1980) Age of the basement rocks of southwest Montana: Geological Society of America Bulletin 91, pt. I, 11-15.

Johnson, R.C., and F.A. Hills (1976) Precambrian geochronology and geology of the Boxelder Canyon area, northern Laramie Range, Wyoming: Geological Society of America Bulletin 87, 809-817.

Karasevich, L.P., J.M. Garihan, P.S. Dahl, and A.F. Okuma (1981) Summary of Precambrian metamorphic and structural history, Ruby Range, southwest Montana: Montana Geological Society 1981 Field Conference, Southwest Montana, 225-237.

Karlstrom, K.E., R.S. Houston, A.J. Flurkey, C.M. Coolidge, A.L. Rratchovil, and C.K. Sever (1981) A summary of the geology and uranium potential of Precambrian conglomerates in southeastern Wyoming $I$ : U.S. Department of Energy Report DJBX-139-81, 1-541.

Kerr, R.A., and R.L. Langenheim, Jr. (1977) Reconnaissance geology of Precambrian rocks near Steamboat Point, Bighorn Mountains, Sheridan County, Wyoming: Wyoming Geological Association Earth Science Bulletin 10, no. 3, 21-28.

K11lsgaard, T.H., G.E. Ericksen, L.L. Patten, and C.L. Bieniewski (1972) Mineral resources of the Cloud Peak Primitive Area, Wyoming: U.S. Geological Survey Bulletin 1371-C, 1-60.

Klein, T.L. (1982a) Archean metavolcanic rocks of the Bradley Peak area, Seminoe Mountains, Wyoming in S.S. Goldich, chairperson, 1982 Archean Geochemistry Field Conference, August 15-19, 1982, Seminoe Mountains and Hartville Uplift, Wyoming, part 1, Guide to Field Trips, 24-49.

Klein, T.L, (1982b) Geology and geochemistry of the Seminoe metavolcanic sequence, Seminoe Mountains, Carbon County, Wyoming: Montana Bureau of Mines and Geology Special Publication 84, 162, 163.

Roehler, S.W. (1976) Petrology of the diabase dikes of the Tobacco Root Mountains, Montana: Montana Bureau of Mines and Geology Special Publication 73 (Guidebook of the Tobacco Root Geological Society 1976 field conference), 27-36.

Lambert, D.D., and E.C. Simmons (1980) Cumulate minerals as liquid analogues, A new approach to modelling trace elements in mafic layered intrusions-Applications to the Stillwater Complex, Montana: EOS (Trans. of AGU) 61, no. 17,410 .

Lambert, D.D., D.M. Unruh, and E.C. Simmons (1982) U-Th-Pb and REE investigation of a trace element-rich zone in the Stillwater Complex, Montana: Geological Society of America Abstracts with Programs 19, no. 7, 539.

Langstaff, G.D. (1984) Investigation of Archean metavolcanic and metasedimentary rocks of Sellers Mountain, west-central Laramie Mountains, Wyoming: Laramie, University of Wyoming, M.S. thesis, 1-260+.

Larson, E.E., R.P. Hoblitt, and R.L. Reynolds (1974) Paleomagnetism of Precambrian dikes in northwestern Wyoming and its use in age dating and understanding the regional tectonic history: EOS (Trans. of AGU) 55, no. 12, 1110,1111 .

Link, P.K., and B.R. Bronson (1984) Archean layered amphibolites and ultramafic pods in the Horseshoe Lake quadrangle, western Wind River Mountains, Wyoming: Geological Society of America Abstracts with Programs $16,228$.

LInk, P.K., and G.B. Le Febre (1983) Upper Proterozoic diamictites and 
volcanic rocks of the Pocatello Formation and correlative units, southeastern Idaho and northern Utah: Utah Geological and Mineral Survey Special Studies 60, Guidebook Part 2-Geological Society of America Rocky Mountain and Cordilleran Sections Meeting, Salt Lake City, Utah-May 24, $1983,1-32$.

Loferski, P.J. (1986) Petrology of metamorphosed chromite-bearing ultramafic rocks from the Red Lodge district, Montana: U.S. Geological Survey Bulletin $1626-B, 1-34$

Loucks, R.R., W.R. Premo, and G.L. Snyder (1988) Petrology, structure, and age of the Mullen Creek layered mafic complex and age of arc accretion, Medicine Bow Mountains, Wyoming: Geological Society of America Abstracts with Programs 20, no. 7, A73.

Lush, A.P., A.J. McGrew, A.W. Snoke, and J.E. Wright (1988) Allochthonous Archean basement in the northern East Humboldt Range, Nevada: Geology, 16, no. 4, 349-353.

Luth, W.C. (1960) Mafic and ultramafic rocks of the Trallside area, Bighorn Mountains, Wyoming: Iowa City, Iowa State University, M.S. thesis, 1-138.

Manzer, G.K., Jr., and R.A. Heimlich (1974) Petrology and geochemistry of mafic and ultramafic rocks from the northern Bighorn Mountains, Wyoming: Geological Society of America Bulletin 85, no. 5, 703-708.

Manzer, G.K., Jr., R.A. Heimlich, and M.E. Ross (1971) Mineralogic variations across Precambrian mafic dikes in the southern Bighorn Mountains, Wyoming: Compass 48, no. 2, 75-83.

Marvin, R.F., R.E. Zartman, J.D. Obradovitch, and J.E. Harrison (1984) Geochronometric and lead isotope data on samples from the Wallace $1^{\circ} \times 2^{\circ}$ quadrangle, Montana and Idaho: U.S. Geological Survey Miscellaneous Field Studies Map MF 1354-G, scale 1:250,000.

McCallum, I.S., L.D. Raedeke, and E.A. Mathez (1980) Investigations of the Stillwater Complex--Part I, Stratigraphy and structure of the Banded Zone: American Journal of Science 280-A, 59-87.

McCulloch, W.R., and M.L. Cummings (1987) Metasomatism between Archean age metamorphosed mafic and ultramafic rock, Tobacco Root Mountains, Montana: Geological Society of America Abstracts with Programs 19, no. 5, 320 .

McCulloch, W.R., and M.L. Cummings (1988) Metamorphic assemblages in mafic and ultramafic bulk compositions, Tobacco Root Mountains, southwest Montana: Geological Society of America Abstracts with Programs 20, no. 6, 431.

McMechan, M.E. (1979) Geology of the Mount Fisher-Sand Creek area: British Columbia Ministry of Energy, Mines and Petroleum Resources Preliminary Map 34, scale $1: 25,000$.

Miller, D.M. (1980) Structural geology of the northern Albion Mountains, south-central Idaho: Geological Society of America Memoir 153, 399-423.

Mudge, M.R., R.L. Earhart, J.W. Whipple, and J.E. Harrison (1982) Geologic and structure map of the Choteau $1^{\circ} \times 2^{\circ}$ quadrangle, western Montana: U.S. Geological Survey Miscellaneous Investigations Series Map I-1300, scale, $1: 250,000$.

Mueller, P.A. (1979) Age of deformation in the Hellroaring Plateau area, eastern Beartooth Mountains, Montana: Canadian Journal of Earth Science 16, 1124-1129.

Mueller, P.A., and J.J.W. Rogers (1973) Secular chemical varlation in a series of Precambrian mafic rocks, Beartooth Mountains, Montana and Wyoming: Geological Society of America Bulletin 84, no. 11, 3645-3652.

Mueller, P.A., J.L. Wooden, A.L. Odom, and D.R. Bowes (1982) Geochemistry of the Archean rocks of the Quad Creek and Hellroaring Plateau areas of the eastern Beartooth Mountalns: Montana Bureau of Mines and Geology Special 
Publication 84, 69-82.

Myers, J.D. and A.D. Patchen (1987) The Lake Owen Mafic Complex, SE Wyoming: I. geologic field relations: EOS (Trans. of AGU) 68, no. 16, 430.

Nelson, G.C. (1969) A preliminary Investigation of Precambrian mafic dikes in the Hess Mountain-Hazelton Peak area, Bighorn Mountains, Wyoming: Compass 46, no. 4, 217-228.

Nunes, P.D., and G.R. Tilton (1971) Uranium-lead ages of minerals from the Stillwater igneous complex and associated rocks, Montana: Geological Society of America Bulletin 82, no. 8, 2231-2249.

Oftedahl, C. (1953) Petrologic reconnaissance of the Pre-Cambrian of the western part of the Wind River Mountains, Wyoming: Norsk Geol. Tidsskr. 32, no. $1,1-17$.

Obradovich, J.D., R.E. Zartman, and Z.E. Peterman (1984) Update of the geochronology of the Belt Supergroup: Montana Bureau of Mines and Geology Special Publication 90, 82-84.

$0^{-}$Neill, J.M., M.S. Duncan, and R.E. Zartman (in press 1988) An Early Proterozoic gneiss dome in the Highland Mountalns of southwestern Montana: Montana Bureau of Mines and Geology Special Paper to accompany 8th International Conference on Basement Tectonics, Field guide to basement rocks of southwestern Montana, $23 \mathrm{~ms}$. p.

0sterwald, F.W. (1955) Petrology of Precambrian granites in the northern Bighorn Mountains, Wyoming: Journal of Geology 63, 310-327.

Osterwald, F.W. (1959) Structure and petrology of the northern Bighorn Mountalns, Wyoming: Wyoming Geological Survey Bulletin 48, 1-47.

Page, N.J., and W.J. Nokleberg (1974) Geologic map of the Stillwater Complex, Montana: U.S. Geological Survey Miscellaneous Investigations Series Map I-797, scale $1: 12,000$.

Pallister, J.S., and Aleinikoff, J.N. (1987) Gabbroic plutons south of the Cheyenne Belt: Underpinnings of an Early Proterozoic continental-margin arc: Geological Society of America Abstracts with Programs 19, no. 5, 325.

Patchen, A.D., and J.D. Myers (1987) The Lake Owen Mafic Complex, SE Wyoming: II. mineralogy and compositional characteristics: EOS (Trans. of AGU) 68 , no. 16,430 .

Pearson, R.C., T.H. Killsgaard, L.L. Patten, and R.E. Mattick (1971) Mineral resources of the Popo Agle primitive area, Fremont and Sublette Counties, Wyoming: U.S. Geological Survey Bulletin 1353-B, 1-55.

Pearson, R.C., L.L. Patten, and D.L. Gaskill (1973) Mineral resources of an area near the Popo Agie Primitive Area, Fremont County, Wyoming: U.S. Geological Survey Bulletin 1391-A, 1-18.

Perry, K., Jr. (1965) High-grade regional metamorphisw of Precambrian gneisses and associated rocks, Paradise Basin quadrangle, Wind River Mountains, Wyoming: New Haven, Yale University, Ph.D. thesis, 1-171.

Peterman, Z.E. (1981) Dating of Archean basement in northeastern Montana: Geological Society of America Bullet1n, Part 1, 92, 139-146.

Peterman, Z.E. (1982) Geochronology of the southern Wyoming age province--a summary in S.S. Goldich, chalrperson: 1982 Archean Geochemistry Field Conference, August 15-19, 1982, Seminoe Mountains and Hartville Uplift, Wyoming; part 1, Gulde to Field Trips, 1-23.

Peterman, Z.E., and R. Futa (1987) Is the Archean Wyoming province exotic to the Superior craton? Evidence from $\mathrm{Sm-Nd}$ model ages of basement cores: Geological Society of America Abstracts with Programs, 19, 803.

Peterman, Z.E., and R.A. Hildreth (1978) Reconnaissance geology and geochronology of the Precambrian of the Granite Mountains, Wyoming: U.S. Geological Survey Professional Paper 1055, 1-22. 
Peterman, Z.E., R.A. Hildreth, and I. Nkomo (1971) Precambrian geology and geochronology of the Granite Mountains, central Wyoming: Geological Society of America Abstracts with Programs 3, 403, 404.

Premo, W.R. and W.R. Van Schmus (in press 1988) Zircon geochronology of Precambrian rocks in southeastern Wyoming and northern Colorado in Proterozoic geology of the Southern Rockies: Geological Society of America Special Paper

Premo, W.R., M. Tatsumoto, R.T. Helz, and M.L. Zientek (1986) A zircon age for St1llwater complex-related rocks: Geological Society of America Abstracts with Programs 18, no. 6, 722 .

Prinz, M. (1964) Geologic evolution of the southern Beartooth Mountains, Montana and Wyoming. Part 5. Mafic dike swarms of the southern Beartooth Mountains: Geological Society of America Bulletin 75, no. 12, 1217-1248. Prinz, M. (1965) Structural relationships of mafic dikes in the Beartooth Mountains, Montana-Wyoming: Journal of Geology 73, 165-179.

Raby, A.G., K.C. Condie, and P. Allen (1979) Geochemical model for the origin of Archean diabase dikes from the eastern Beartooth Mountains, Montana and Wyoming, in Precambrian Geology of the Beartooth Mountains, Montana and Wyoming: Montana Bureau of Mines and Geology Special Publication 84, 164.

Redden, J.A. (1980) Geology and uranium resources in Precambrian conglomerates of the Nemo area, Black Hills, South Dakota: U.S. Department of Energy Report GJBX 127 ( 80$)$, 1-147; available from U.S. Geological Survey, OpenFile Services Section, P.0. Box 25425, Denver, CO 80225.

Redden, J.A. (1981) Summary of the geology of the Nemo area in Rich, F.J., ed., Geology of the Black Hills, South Dakota and Wyoming: Geological Society of America Guidebook, Rocky Mountain Section, Annual Meeting, Rapid City, S. Dak., 1981: Falls Church, Va., American Geological Institute, 193210 .

Redden, J.A., Z.E. Peterman, R.E. Zartman, and E.J. DeWitt (in press 1988) $\mathrm{U}-\mathrm{Th}-\mathrm{Pb}$ geochronology and preliminary interpretation of Precambrian tectonic events in the Black Hills, South Dakota: Geological Association of CanadaMineralogical Association of Canada Trans-Hudson orogeny symposium volume, 37 ms. p.

Reed, J.C., Jr. (1987) Precambrian geology of the U.S.A.: Episodes, 10, 243247.

Reed, J.C., Jr., M.E. Bickford, W.R. Premo, J.N. Aleinikoff, and J.S. Pallister (1987) Evolution of the Early Proterozoic Colorado province: Constraints from $\mathrm{U}-\mathrm{Pb}$ geochronology: Geology 15, no. 9, 861-865.

Reed, J.C., Jr., and R.E. Zartman (1972) Geochronology of Precambrian rocks of the Teton Range, Grand Teton National Park, Wyoming: Geological Society of America Abstracts with Programs 4, no. 6, 403, 404.

Reed, J.C., Jr., and R.E. Zartman (1973) Geochronology of Precambrian rocks of the Teton Range, Wyoming: Geological Society of America Bulletin 84, 561582.

Reid, R.R., W.J. McMannis, and J.C. Palmquist (1975) Precambrian geology of North Snowy Block, Beartooth Mountains, Montana: Geological Society of America Special Paper 157, 1-135.

Rember, W.C., and E.H. Bennett (1979) Geologic map of the Hamilton quadrangle, Idaho: Idaho Bureau of Mines and Geology Geologic Map Series, scale $1: 250,000$.

Ritzma, H.R. (1980) Diorite dike, eastern Uinta Mountains, Daggett and Duchesne Counties, Utah: Geological Society of America Abstracts with Programs (Weber State College, May, 1980), 302.

Ross, C.P., and D.J. Forester (1946) Geologic map of the State of Idaho: U.S. 
Geological Survey and Idaho Bureau of Mines and Geology, scale 1:500,000. Ross, C.P., B.A.L. Skipp, and R. Rezak, (1963) The Belt Series in Montana: U.S. Geological Survey Professional Paper 346, 1-122.

Ross, M.E., and R.A. Helmlich (1972) Petrology of Precambrian mafic dikes from the Bald Mountain area, Bighorn Mountains, Wyoming: Geological Society of America Bulletin 83, 1117-1124.

Rowan, L.C., and L.H. Larsen (1970) Precambrian history of the Beartooth Mountains - Hellroaring Lakes area, Montana: Geological Society of America Abstracts with Programs 2, no. 5, 347.

Ruppel, E.T., J.M. O'Neill, and D.A. Lopez (1983) Preliminary geologic map of the Dillon $1^{\circ} \times 2^{\circ}$ quadrangle, Montana: U.S. Geological Survey Open-File Report 83-168, scale $1: 250,000$.

Ryder, G., and B. Spettel (1985) The parental magma for some rocks from the Norite I Subzone of the Stillwater Complex-A Lunar analog study: Proceedings of the 15th Lunar and Planetary Science Conference, Part 2: Journal of Geophysical Research 90, Supplement, C591-C600.

Salzer, S.D., and K.V. Hodges (1988) The Middle Mountain shear zone, southern Idaho: Kinematic analysis of an early Tertiary high temperature detachment: Geological Society of America Bulletin 100, no. 1, 91-103.

Schmidt, C.J., and J.M. Garihan (1986) Middle Proterozoic and Laramide tectonic activity along the southern margin of the Belt Basin: Montana Bureau of Mines and Geology Special Publication 94 on Belt Supergroup: A guide to Proterozoic rocks of western liontana and adjacent areas, 217-235.

Scholten, R., K.A. Keenmon, and W.0. Kupsch (1955) Geology of the Lima region, southwestern Montana and adjacent Idaho: Geological Society of America Bulletin 66, no. 4, 345-403.

Segerstrom, $K_{.}$, and R.R. Carlson (1982) Geologic map of the Banded Upper Zone of the Stillwater Complex and adjacent rocks, Stillwater, Sweet Grass, and Park Counties, Montana: U.S. Geological Survey Miscellaneous Investigations Series Map I-1383, scale $1: 24,000$.

Segerstrom, K., R.C. Weisner, and D.B. Jackson (1976) Mineral resources of areas adjacent to the Cloud Peak Primitive Area, Wyoming: U.S. Geological Survey Bulletin 1391-D, 1-37.

Shaw, H.F., R.J. Tracy, S. Niemeyer, and D. Colodner (1986) Age and Nd-Sr systematics of the Spring Creek Lake body, Sierra Madre Mtns., WY: EOS (Trans. of AGU) 67, no. 44, 1266.

Simons, F.S., T.J. Armbrustmacher, R.M. Van Noy, N.T. Zilka, F.E. Federspiel, J. Ridenour, and L.A. Anderson (1979) Mineral resources of the Beartooth Primitive Area and vicinity, Carbon, Park, Stillwater, and Sweet Grass Counties, Montana, and Park County, Wyoming: U.S. Geological Survey Bulletin 1391-F, 1-125.

Simons, F.S., W.R. Keefer, D.S. Harwood, and J.D. Love (1981) Mineral resources of the Gros Ventre Wilderness Study Area, Teton and Sublette Counties, Wyoming: U.S. Geological Survey Open-File Report 81-510, 1-93, maps in two envelopes, scale $1: 48,000$.

Skinner, W.R. (1969) Geologic evolution of the Beartooth Mountains, Montana and Wyoming: Part 8. Ultramafic rocks in the Highline Trail Lakes area, Wyoming: Geological Society of America Memoir 115, p. 19-52.

Skinner, W.R., D.R. Bowes, and S.G. Khoury (1969) Polyphase deformation in the Archean basement complex, Beartooth Mountains, Montana and Wyoming:

Geological Society of America Bulletin 80, no. 6, 1053-1060.

Snyder, G.L. (1980a) Geologic map of the northernmost Park Range and southernmost Sierra Madre, Jackson and Routt Counties, Colorado: U.S. Geological Survey Miscellaneous Investigations Series Map I-1113, scale 
$1: 48,000$.

Snyder, G.L. (1980b) Map of Precambrian and adjacent Phanerozolc rocks of the Hartville Uplift, Goshen, Niobrara, and Platte Countles, Wyoming: U.S. Geological Survey Open-File Report 80-779, 1-11, 2 map sheet8, scale $1: 48,000$.

Snyder, G.L. (1984) Preliminary geologic maps of the central Laramie Mountains, Albany and Platte Counties, Wyoming: U.S. Geological Survey Open-File Report 84-358 (Parts A-M), scale 1:24,000.

Snyder, G.L. (1986) Preliminary geologic maps of the Reese Mountain and part of the Hightower SW 7.5 minute quadrangles (Part A) and parts of the Fletcher Park and Johnson Mountain 7.5 minute quadrangles (Part B), Albany and Platte Counties, Wyoming: U.S. Geological Survey Open-File Report 86201, 1-16, 2 map sheets, scale $1: 24,000$.

Snyder, G.L., W.D. Hausel, T.L. Klein, R.S. Houston, and P.J. Graff (1989) Precambrian rocks and mineralization, southern Wyoming Province: $28 \mathrm{th}$ International Geological Congress, Guide to IGC Field Trip T-332, 1-48. Snyder, G.L. and C.E. Hedge (1978) Intrusive rocks northeast of Steamboat Springs, Park Range, Colorado: U.S. Geological Survey Professional Paper $1041,1-42$.

Snyder, G.L. and Z.E. Peterman (1982) Precambrian geology and geochronology of the Hartville Uplift, Wyoming, in S.S. Goldich, chairperson, 1982 Archean Geochemistry Field Conference, August 15-19, 1982, Seminoe Mountains and Hartville Uplift, Wyoming, part 1, Guide to Field Trips, 64-94.

Spa11, H. (1971) Paleomagnetism and $\mathrm{K}-\mathrm{Ar}$ age of mafic dikes from the Wind River Range, Wyoming: Geological Society of America Bulletin 82, no.9, 2457-2472.

Spencer, E.W., and S.J. Kozak (1975) Precambrian evolution of the Spanish Peaks area, Montana: Geological Soclety of America Bulletin 86, 785-792.

Stuckless, J.S., C.M. Bunker, C.A. Bush, W.P. Doering, and J.H. Scott (1977) Geochemical and petrological studies of a uraniferous granite from the Granite Mountains, Wyoming: U.S. Geological Survey Journal of Research 5, no. 1, 61-81.

Stuckless, J.S., C.E. Hedge, R.G. Worl, K.R. Simmons, L.T. Nkomo, and D.B. Wenner (1985) Isotopic studies of the Late Archean plutonic rocks of the Wind River Range, Wyoming: Geological Society of America Bulletin 96, 850860.

Stuckless, J.S., L.T. Nkomo, and B.R. Doe (1981) U-Th-Pb systematics in hydrothermally altered granites from the Granite Mountains, Wyoming: Geochimica et Cosmochimica Acta 45, no. 5, 635-645.

Stuckles6, J.S., and Z.E. Peterman (1977) A summary of the geology, geochronology, and geochemistry of Archean rocks of the Granite Mountains, Wyoming: Wyoming Geological Association Earth Sclence Bulletin 10, no.3, 3$20 \mathrm{D}$.

Stueber, A.M., R.A. Heimlich, and M. Ikramuddin (1974) Rb-Sr ages of Precambrian mafic dikes from the Bighorn Mountains, Wyoming: EOS (Trans. of AGU) 56, no. 12, $1198,1199$.

Stueber, A.M., R.A. Heimlich, and M. Ikramuddin (1976) Rb-Sr ages of Precambian mafic dikes from the Bighorn Mountains, Wyoming: Geological Society of America Bulletin 87, no. 6, 909-914.

Thaden, R.E. (1980a) Geologic map of the DePass quadrangle, Fremont and Hot Springs Counties, Wyoming: U.S. Geological Survey Geologic Quadrangle Map GQ-1526, scale $1: 24,000$.

Thaden, R.E. (1980b) Geologic map of the Guffy Peak quadrangle, Fremont and Hot Springs Counties, Wyoming: U.S. Geological Survey Geologic Quadrangle 
Map GQ-1527, scale $1: 24,000$.

Thaden, R.E. (1980c) Geologic map of the Birdseye Pass quadrangle, showing chromolithofacies and coal beds in the Wind River Formation, Fremont and Hot Springs Counties, Wyoming: U.S. Geological Survey Geologic Quadrangle Map GQ-1537, scale $1: 24,000$.

Timm, R.W. (1982) Mineralogy and petrology of some metasedimentary xenoliths in granite gneisses of the Broadwater River area, Beartooth Mountains, Montana in Precambrian geology of the Beartooth Mountains, Montana and Wyoming: Montana Bureau of Mines and Geology Special Publication 84, 25-40.

Todd, S.G., D.J. Schissel, and T.N. Irvine (1979) Lithostratigraphic variations associated with the platinum-rich zone of the Stillwater Complex: Carnegie Institution of Washington, Annual Report of the Director, Geophysical Laboratory, 461-468.

Todd, V.R. (1980) Structure and petrology of a Tertlary gneiss complex in northwestern Utah: Geological Society of America Memoir 153, 349-383.

Tracy, R.J., D. Colodner, J. Longhi, and H. Shaw (1986) Petrology of Precambrian ultramafic-mafic bodies, south-central Wyoming: Eos (Trans. of AGU) 67, no. 44, 1265 .

Tweto, 0. (1987) Rock units of the Precambrian basement in Colorado: U.S. Geological Survey Professional Paper 1321-A, A1-A54.

Tysdal, R.G., G.K. Lee, J.H. Hassemer, W.F. Hanna, S.W. Schmauch, and R.B. Berg (1987) Mineral resources of the Ruby Mountains Wilderness Study Area, Madison County, Montana: U.S. Geological Survey Bulletin 1724, 1-22.

Vitaliano, C.J., W.S. Cordua, H.R. Burger III, T.B. Hanley, D.F. Hess, and F.K. Root (1979) Explanatory text to accompany geologic map of southern Tobacco Root Mountains, Madison County, Montana: Geological Society of America Map and Chart Series MC-31, 1-8, scale 1:62,500; and Geology and structure of the southern part of the Tobacco Root Mountains, southwestern Montana: Map summary: Geological Society of America Bulletin 90 (Part I), 712-715.

Wahlstrom, E.E. (1956) Petrology and weathering of the Iron Dike, Boulder and Larimer Counties, Colorado: Geological Society of America Bulletin 67, no. 2, 147-163.

Wallace, C.A., compiler (1987) Generalized geologic map of the Butte $1^{\circ} \times 2^{\circ}$ quadrangle, Montana: U.S. Geological Survey Miscellaneous Field Studies Map MF-1925, scale, $1: 250,000$.

Wallace, C.A., R.G. Schmidt, D.J. Lidke, M.R. Waters, J.E. Elliott, A.B. French, J.W. Whipple, S.E. Zarske, M.J. Blaskowsk1, B.A. Heise, R.A. Yeoman, J.H. $0^{-}$Ne1l1, D.A. Lopez, G.D. Robinson, and M.R. Rlepper (1987) Preliminary map of the Butte $1^{\circ} \times 2^{\circ}$ quadrangle, western Montana: U.S. Geological Survey Open-F1le Report 86-292, scale 1:250,000.

Wedow, H., Jr., D.J. Gaskill, D.P. Banister, E.C. Pattee, and D.L. Peterson (1975) Mineral resources of the Absaroka Primitive Area and vicinity, Park and Sweet Grass Counties, Montana: U.S. Geological Survey Bulletin 1391-B, $1-115$.

Wells, R.A. (1975) Structural analysis of Precambrian rocks in northeastern Badwater quadrangle, Wyoming: Laramle, University of Wyoming M.S. thesis, $1-48$.

Witkind, I.J. (1971) Geologic map of the Barker quadrangle, Judith Basin and Cascade Counties, Montana: U.S. Geological Survey Geological Quadrangle Map GQ-898, scale $1: 62,500$.

W1tkind, I.J. (1972) Geologic map of the Henrys Lake quadrangle, Idaho and Montana: U.S. Geological Survey Miscellaneous Investigations Serles Map I-781-A, scale 1:62,500. 
Witkind, I.J. (1976) Geologic map of the southern part of the Upper Red Rock Lake quadrangle, southwestern Montana and adjacent Idaho: U.S. Geological Survey Miscellaneous Investigations Map Series I-943, scale 1:62,500.

Wooden, J.L. (1975) Geochemistry and Rb-Sr geochronology of Precambrian mafic dikes from the Beartooth, Ruby Range, and Tobacco Root Mountains, Montana: Chapel Hill, University of North Carolina Ph.D. thesis, 1-201.

Wooden, J.L., and P.A. Mueller (1979) Mafic dikes of the Beartooth Mountains: Guide to the Precambrian rocks of the Beartooth Mountains (1979 Field Conference of the Archean Geochemistry Working Group, IGCP), 50-61.

Wooden, J.L., C.J. Vitaliano, S.W. Koehler, and P.C. Ragland (1978) The late Precambrian mafic dikes of the southern Tobacco Root Mountains, Montana: geochemistry, Rb-Sr geochronology and relationship to Belt tectonics: Canadian Journal of Earth Sciences 15, no. 4, 467-479.

Worl, R.G. (1963a) Superimposed deformations in Precambrian rocks near South Pass, Wyoming: Laramie, University of Wyoming M.S. thesis, 1-53.

Worl, R.G. (1963b) Superposed deformations in Precambrian rocks near South Pass, Wyoming: University of Wyoming Contributions to Geology 2, no. 2, 109-116.

Worl, R.G. (1967) Taconite and migmatite in the northern Wind River Mountains, Fremont, Sublette, and Teton Counties, Wyoming: Laramie University of Wyoming Ph.D. thesis, 1-130.

Worl, R.G. (1968) Taconite in the Wind River Mountains, Sublette County, Wyoming: Wyoming Geological Survey Preliminary Report 10, 1-15.

Worl, R.G. (1969) Migmatites in the Three Waters area, northern Wind River Mountains, Wyoming: Geological Society of America Special Paper 121, 647, 648.

Worl, R.G. (1972) Layered paratectonic migmatites of the Three Waters area, Wind River Range, Wyoming, U.S.A.: 24th International Geological Congress Proceedings, Section 2, 135-143.

Worl, R.G., G.K. Lee, C.L. Long, and G.S. Ryan (1984) Mineral resource potential map of the Bridger Wilderness and the Green-Sweetwater Roadless Area, Sublette and Fremont Countles, Wyoming: U.S. Geological Survey Miscellaneous Field Studies Map MF-1636-A, 1-12.

Worl, R.G., M.E. Koesterer, and T.P. Hulsebosch (1986) Geologic map of the Bridger Wilderness and the Green-Sweetwater Roadless Area, Sublette and Fremont Counties, Wyoming: U.S. Geological Survey Miscellaneous Field Studies Map MF-1636-B, 8cale 1:250,000.

Zartman, R.E., Z.E. Peterman, J.D. Obradovich, M.D. Gallego, and D.T. Bishop (1982) Age of the Crossport C sill near Eastport, Idaho in Society of Economic Geologists Coeur d'Alene Field Conference, Idaho-1977: Idaho Bureau of Mines and Geology Bulletin 24, 61-69.

Zientek, M.L. (1983) Petrogenesis of the Basal Zone of the Stillwater Complex, Montana: Stanford, California, Stanford University Ph.D. thesis, 1-246. Also Dissertation Abstracts International 45, 105B-106B. 